\title{
Obraz Bożego Narodzenia i Wielkanocy w języku dziesięcioletnich dzieci
}

\author{
The Image of Christmas and Easter \\ in the Language of Ten-Year-Old Children
}

Summary: The article presents the ways of conceptualisation, i.e. the mental representations of the holidays celebrated in Poland by ten-year-old children. Christmas and Easter are Catholic holidays, well-established in culture, tradition and religion. On account of the subject of the research and the linguistic characteristics of Easter and Christmas, we have chosen a cognitive methodology of description, which enabled us to look at the collected material (vocabulary), at the evaluation of selected phenomena, and at the emotional attitude to the expressed judgments from a different angle.

Key words: cognitive definition, ten-year-old children, Christmas, Easter

Człowiek [...] - jak wiemy od Arystotelesa — jest istotą posiadającą Logos. A Logos to słowo mające znaczenie i sens.

Kazimiera Krakowiak ${ }^{1}$

Dzieci w sposób niezwykle aktywny, twórczy i wyjątkowy poznają świat. Czynią to dzięki językowi. To właśnie język umożliwia im poznanie:

${ }^{1}$ K. Krakowiak: Wspólne doświadczanie języka. (Rozważania o wychowaniu językowym dzieci z uszkodzeniami słuchu). W: Język, człowiek, społeczeństwo. Księga jubileuszowa dedykowana Profesorowi Stanistawowi Grabiasowi. Red. J. Panasiuk, T. Woźniak. Lublin 2013, s. 491. 
Wraz z nabywaniem języka przyjmuje [dziecko - U.J., N.P.] olbrzymi skarbiec doświadczeń i przeżyć, który dany naród zebrał w swoim języku $\mathrm{w}$ przeciągu tysiącleci² .

Wygłaszane przez nie sądy, dłuższe teksty, a nawet codzienne komunikaty są źródłem informacji dla dorosłych użytkowników języka „o sposobach kategoryzowania przez nie otaczającego świata oraz o samych dzieciach"”. W okresie dzieciństwa szczególnie mocno i wnikliwie doświadczają „,czasu i przestrzeni”"4.

W artykule chcemy pokazać, w jaki sposób dziesięcioletnie dzieci, a zatem te, które zakończyły edukację wczesnoszkolną i rozpoczynają kolejny okres nauki, postrzegają Boże Narodzenie oraz Wielkanoc ${ }^{5}$. „Chcąc zrozumieć, jak konstruowana jest umysłowa reprezentacja dziecięcych narracji”, która jest efektem procesu rozumienia, czyli tego, co badani mają na myśli, konstruując znaczenie, sięgnęłyśmy do dwóch najbardziej utrwalonych w kulturze, religii i tradycji świąt. Literatura i sztuka, wreszcie doświadczenia każdego z nas, pokazują, że te dwa święta to czas wyjątkowy, rodzinny i radosny. Na przestrzeni dziejów wykształciła się związana z nimi bogata obrzędowość religijna i świecka. Symbolika opłatka, historia choinki, kolędy, pastorałki, kolacja wigilijna oraz prezenty od św. Mikołaja to tylko niektóre elementy związane z tradycją i religijną oprawą zupełnie wyjątkowych grudniowych dni. Także święcenie pokarmów, malowanie pisanek, Triduum Paschalne, niezwykle bogata celebra religijna świąt wielkanocnych oraz domowe porządki kojarzone z nadejściem wiosny wydają się bogato zakorzenione w naszej kulturze i obrzędowości.

Ze względu na tematykę badań oraz językowe charakterystyki świąt, zdecydowałyśmy się na wybór kognitywnej metodologii opisu, która pozwoliła nam w sposób wieloaspektowy spojrzeć na zgromadzony w toku badań materiał (leksykę), wartościowanie wybranych zjawisk oraz emocjonalny stosunek do wygłaszanych sądów. Kognitywna koncepcja znaczenia, którą zastosowałyśmy do analizy wypowiedzi badanych dzieci, jest bliska badaniom psychologicznym, ponieważ podkreśla się w niej znaczenie procesów poznawczych (spostrzegania, myślenia, uwagi) w rozwoju językowym.

${ }^{2}$ F. Tschirch: Denkform und Sprachgestalt. Grundauffassungen und Fragestellungen in der heutigen Sprachwissenschaft. Berlin 1954, s. 68.

${ }^{3}$ B. Niesporek-Sza mburska: Językowy obraz pór roku i tradycji kulturowych w twórczości dzieci. Katowice 2004, s. 7.

${ }^{4}$ Ibidem.

${ }^{5}$ Opisane w artykule dziecięce konceptualizacje są fragmentem badań nad rozumieniem świąt kościelnych i świeckich obchodzonych w Polsce. Z uwagi na rozmiar artykułu przedstawiamy tylko dwa z nich, mianowicie Boże Narodzenie i Wielkanoc. Badania właściwe obejmowały trzy święta kościelne: Wielkanoc, Wszystkich Świętych, Boże Narodzenie, a także Dzień Matki i walentynki.

${ }^{6} \mathrm{M}$. Wiśniews ska-Kin: Dziecięce rozumienie świata - w poszukiwaniu uzasadnień postępowania badawczego. „Problemy Współczesnej Edukacji” 2016, nr 1, s. 67. 
Decydując się na opis relacji, jaka istnieje między językiem, myśleniem i rzeczywistością, a także chcąc pokazać, jakie są sposoby organizowania i wyrażania w języku wiedzy o świecie, należy przyjąć (zgodnie z założeniami gramatyki kognitywnej), że „informacja, jaką nam język przekazuje, [...] składa się z wyobrażeń tworzących strukturę konceptualną"7 , sama zaś dotyczy „świata projektowanego". Przy czym świat realny i projektowany są ,izomorficzne względem siebie”, czyli ,świat projektowany jest w zasadzie repliką świata realnego" ${ }^{8}$. Gramatyka kognitywna bada obraz tego świata w umyśle człowieka. Zgodnie z Langackerowską teorią języka:

nasz umysł nie tylko biernie rejestruje doświadczenie, ale bierze czynny udział w budowaniu, manipulowaniu i modyfikowaniu rozbudowanych struktur pojęciowych, które wspólnie tworzą nasz mentalny świat. Czynność wyobrażeniowa - konceptualizacja - nie przebiega w sposób mechaniczny [...]. Poprzez projekcje i konstrukcje myślowe jesteśmy w stanie konceptualizować niezliczone sytuacje, nawet całe światy, które nie były i często nie mogą być doświadczane bezpośrednio9.

Perspektywa ta nakazuje zatem przyjęcie modelu kognitywnej definicji znaczenia, która jest typem definicji potocznej, zbudowanej w oparciu o wiedzę, doświadczenie zwykłego użytkownika języka oraz przekazy kulturowe. Zgodnie z założeniami Jerzego Bartmińskiego:

jednostką podlegającą definiowaniu jest „przedmiot mentalny” w całym bogactwie jego charakterystyki utrwalonej w językowym obrazie świata. Ten ,przedmiot mentalny” jest projekcją, a nie odbiciem, niezależnie od tego, że zwykle istnieje możliwość porównania go (i stwierdzenia podobieństw) z przedmiotem rzeczywistym, dostępnym doświadczeniu empirycznemu ${ }^{10}$.

Podstawowym celem tego typu definicji jest:

zdanie sprawy ze sposobu pojmowania przedmiotu przez mówiących danym językiem, tj. ze sposobu utrwalonej społecznie i dającej się poznać

${ }^{7}$ H. Kardela: Ogdena i Richardsa trójką uzupetniony, czyli co bada gramatyka kognitywna. W: Językowy obraz świata. Red. J. Bartmiński. Lublin 1999, s. 21.

8 Ibidem.

9 Fragment wykładu Ronalda Langackera wygłoszonego na Uniwersytecie Łódzkim 1 października 2003 roku. Cyt. za: M. Wiśniew ska-Kin: „Chcieć, pragnać, myśleć, wiedzieć”-rozumienie pojęć przez dzieci. Kraków 2007, s. 32.

${ }^{10}$ J. Bartmiński, S. Niebrzegowska: Profile a podmiotowa interpretacja świata. W: Profilowanie wjęzyku i w tekście. Red. J. Bartmiński, R. Tokarski. Lublin 1998, s. 212. 
poprzez język i użycie języka wiedzy o świecie, kategoryzacji jego zjawisk, ich charakterystyki i wartościowania ${ }^{11}$.

Definicja znaczeniowa, w tym ujęciu określona jako „eksplikacja semantyczna”, zmierza w kierunku opisu cech określanych mianem „konotacyjnych i asocjacyjnych”. „Operuje formułą opisu otwartego. Włącza cytaty jako elementy integralne definicji”, które spełniają funkcje „eksplikacyjne”'2. W myśl definicji kognitywnej:

definicje słowa $[\ldots]$ muszą uwzględniać szerokie spektrum składników znaczeniowych, nie mogą ograniczać się do cech wystarczających i koniecznych ${ }^{13}$.

Zgodnie z powyższym, świadomość człowieka jako podmiotu poznania jest rodzajem filtra, który przepuszcza postrzegane zjawiska zanim zostaną one wyrażone $\mathrm{w}$ języku ${ }^{14}$. Opis znaczenia jest ,zrelatywizowany do człowieka”, wobec tego jednym $z$ aspektów naszych badań jest pokazanie, w jaki sposób dzieci porządkują dostępną im rzeczywistość, które zjawiska uważają za ważne, co wybierają (,z ogółu cech utrwalonych w języku” ${ }^{\prime \prime}$ ) podczas definiowania świąt.

W artykule staramy się pokazać, jaka jest wewnętrzna struktura semantyczna oraz ,hierarchia cech znaczeniowych w obrębie tworzonej przez ucznia definicji pojęcia"17 Bożego Narodzenia i Wielkanocy. W postępowaniu badawczym zmierzamy do skonstruowania definicji kognitywnej poprzez uporządkowanie fasetowe cech definicyjnych (co Anna Wierzbicka określa mianem „struktury kognitywnej pojęcia"). Naszym zamiarem jest pokazanie sposobu konceptualizacji tego fragmentu rzeczywistości, który związany jest z obchodzeniem wybranych świąt kościelnych. W efekcie zmierzamy do zaprezentowania tego, jaki ,językowy obraz świąt” wyłania się z powstałych interpretacji dziecięcych.

11 J. Bartmiński: Definicja kognitywna jako narzędzie opisu konotacji. W: O definicjach i definiowaniu. Red. J. Bartmiński, R. Tokarski. Lublin 1993, s. 169-170.

12 J. Bartmiński, R. Tokarski: Definicja semantyczna: czego i dla kogo?. W: O definicjach i definiowaniu..., s. 59.

${ }^{13}$ R. Tokarski: Ramy interpretacyjne a problemy kategoryzacji (przyczynek do tak zwanej definicji kognitywnej). W: Językowa kategoryzacja świata. Red. R. Grzegorczykowa, A. Pajdzińska. Lublin 1996, s. 99.

${ }^{14}$ Zob. A. Heinz: Język a inne dziedziny działalności człowieka. „Biuletyn Polskiego Towarzystwa Językoznawczego" 1981, z. 38, s. 142-157; M. Marody: Technologie intelektu. Językowe determinanty wiedzy potocznej i ludzkiego działania. Warszawa 1987.

15 J. Bartmiński: O profilowaniu i profilach raz jeszcze. W: O definicjach i definiowaniu..., s. 269 .

16 Ibidem.

${ }^{17}$ M. Wiśniewska-Kin: „,Chcieć”, „pragnąc”, ,,myśleć”, „,wiedzieć”..., s. 34. 
Znaczenie w ujęciu kognitywnym sprowadza się do opisu „struktur konceptualnych" występujących w umyśle ludzkim ${ }^{18}$. Zawarta w znaczeniu interpretacja rzeczywistości prezentuje pewien sposób widzenia określonego fragmentu rzeczywistości, realizuje się w „ramach pewnego modelu poznawczego" 19 , w którym istotną rolę pełnią „,podmiotowy punkt widzenia" ${ }^{20}$, kategoryzacja ${ }^{21}$, prototyp $^{22}$, myślenie stereotypowe ${ }^{23}$ oraz wartościowanie. Werbalizacja pojęć w języku dzieci wiąże się z ,przekraczaniem dosłowności”, jak to metaforycznie ujęła w swoich rozważaniach Małgorzata Wiśniewska-Kin ${ }^{24}$. Metodologia kognitywna pozwala uchwycić odmienność myślenia dziecka, spontaniczność jego wypowiedzi oraz drogę dochodzenia do znaczenia wyrazu; począwszy od „,potocznej bazy kognitywnej” ${ }^{25}$, poprzez „typową reinterpretację szkolną, „naśladowanie ujęć z języka dorosłych", do własnego oryginalnego ujęcia.

Wydaje się, że zebrany materiał językowy pozwala spojrzeć na myślenie dzieci w zupełnie innym świetle. Chcemy pokazać, że poznanie i wyrażanie dziecięcych spostrzeżeń w języku wiąże się z takimi cechami, jak: samodzielność myślenia, wrażliwość emocjonalna, otwartość na doświadczenia oraz mani-

18 Ibidem.

19 Ibidem.

20 J. Bartmiński: Punkt widzenia, perspektywa, językowy obraz świata. W: Językowy obraz świata..., s. 105.

${ }^{21}$ Kategorie powstają w wyniku procesu tworzenia pojęć. Proces kategoryzacji jest procesem subiektywnym, jego podstaw należy szukać w „doświadczeniu zmysłowym, czyli w procesach percepcji, ponieważ doświadczenie to poprzedza i warunkuje powstanie struktur pojęciowych". E. Tabakowska: Gramatyka i obrazowanie. Wprowadzenie do językoznawstwa kognitywnego. Kraków 1995, s. 40. „Kategoryzacja to dla człowieka przede wszystkim środek do rozumienia świata [...]. Kategoryzacja jest naturalnym sposobem rozpoznawania rodzaju rzeczy lub doświadczenia poprzez uwypuklenie pewnych właściwości, pomniejszenie innych i ukrywanie dalszych". G. Lakoff, M. Jonhson: Metafory w naszym życiu. Tłum. T. Krzeszowski. Warszawa 1988, s. $150,190-191$.

${ }^{22}$ W myśl teorii zaproponowanej przez Eleanor Rosch ,kategoryzujemy rzeczy w terminach prototypów”. Prototyp jest najlepszym egzemplarzem danej kategorii. Zob. E. Ros ch: Principles of Categorization. W: Cognition and Categorization. Ed. E. Rosch, B. Lloyd. Hillsdale 1978, s. $27-48$.

${ }^{23}$ Przedstawiciele lingwistyki kognitywnej zwrócili uwagę na jeszcze jeden ważny aspekt myślenia, zgodnie z którym w świadomości użytkowników języka utrwalone jest nie tylko wyobrażenie typowego egzemplarza (prototypu), ale również jego ocena, tzw. emocjonalny składnik znaczenia słowa — stereotyp. M. Wiśniewska-Kin: ,,Chcieć”, ,pragnać”, ,myśleć”, ,wiedzieć”..., s. 42. Rozumienie stereotypu przyjmujemy za Jerzym Bartmińskim. Zdaniem badacza stereotyp to ,zbiór sądów skojarzonych z danym pojęciem, utrwalonych w języku”, związany z wartościowaniem, które jest również ważnym składnikiem definicji kognitywnej oraz subiektywizacją znaczenia. J. Bartmiński, J. Panasiuk: Stereotypy językowe. W: Wspótczesny język polski. Red. J. Bartmiński. Lublin 2001, s. 375.

${ }^{24}$ M. Wiśniewska-Kin: „, Chcieć”, ,pragnać”, ,,myśleć”, „,wiedzieć”..., s. 152.

25 Ibidem. 
festowanie przekory wobec utrwalonych schematów mówienia i zachowania dorosłych $^{26}$.

Definicja kognitywna jest niczym innym, jak próbą interpretacji świata, która rozwija się i zmienia wraz z rozwojem kompetencji językowej, komunikacyjnej i kulturowej człowieka ${ }^{27}$. Wyższe bądź niższe sprawności językowe uczniów decydują o sposobie interpretacji wyrazu i kategoryzacji opisywanych pojęć.

Zdecydowałyśmy się na grupę badawczą, którą stanowiły dziesięcioletnie dzieci, z kilku powodów. Uczęszczają one do czwartej klasy szkoły podstawowej, zatem znajdują się w ostatniej fazie okresu operacji konkretnych (zgodnie z terminologią zaproponowaną przez Jeana Piageta). Jedną z właściwości myślenia na tym etapie rozwojowym jest „odwracalność”, która umożliwia „korygowanie potencjalnych zakłóceń i przez to dochodzenie do prawidłowego rozwiązywania problemów" ${ }^{28}$. W okresie tym następuje formowanie się pojęć w wyniku wyodrębniania i uogólniania istotnych cech przedmiotów i zjawisk oraz ich systematyzacja. Dzieci nabierają umiejętności przeprowadzania operacji myślowych bez odwoływania się do konkretnego materiału, potrafią już wyłącznie w myśli zestawiać sądy i wyciągać wnioski na ich podstawie. W młodszym wieku szkolnym mowa, jaką posługują się dzieci, nie ma już charakteru subiektywno-egocentrycznego, przyjmuje postać obiektywno-uspołecznioną.

Dziesięciolatki mają już za sobą blisko czteroletni staż szkolny. W tym okresie więcej czasu spędzają z rówieśnikami niż z rodziną, przez co nabywają nowych doświadczeń oraz oceniają swoje możliwości w różnych sytuacjach życia codziennego. Szkoła w znacznym stopniu przyczynia się do wzrostu ich aktywności językowej.

Piaget ${ }^{29}$ był zdania, że szkolne metody kształcenia są nadmiernie werbalne oraz wymagają dosłownego zapamiętywania. Według niego kształcenie powinno być oparte na naturalnej ciekawości ucznia i jego tendencji do działania w świecie, w celu zrozumienia go. Wiedza staje się bardziej zrozumiała, gdy dzieci budują ją same, niż gdy jest im narzucana.

Badania przeprowadziłyśmy w grupie dziesięciolatków uczęszczających do czwartej klasy liczącej piętnaścioro dzieci. Narzędziem była ankieta zawiera-

${ }^{26}$ Podobne rozważania na temat twórczości językowej dzieci odnajdziemy w książce B. Niesporek-Szamburskiej: Językowy obraz pór roku...

27 S. Grabias: Teoria zaburzeń mowy. Perspektywy badań, typologie zaburzeń, procedury postępowania logopedycznego. W: Logopedia. Teoria zaburzeń mowy. Red. S. Grabias, M. Kurkowski. Lublin 2014, s. 61.

${ }^{28}$ R. Vasta, M.M. Haith, S.A. Miller: Psychologia dziecka. Warszawa 1995, s. 294.

29 J. Piaget: The Theory of Stages in Cognitive Development. W: Measurement and Piaget. Ed. D. Green, M. Ford, G. Flamer. New York 1971, s. 1-7; J. Piaget: The Affective Unconscious and the Cognitive Unconscious. W: Piaget and His School. Ed. B. Inhelder, H. Chapman. New York 1976, s. 63-71. 
jąca taki sam zestaw pytań odnoszących się do każdego święta. Pytania były zadawane według następującego schematu:

- Co robimy, kiedy jest Boże Narodzenie / Wielkanoc?

— Jakie symbole kojarzą Ci się z tym świętem?

— Jaki nastrój towarzyszy temu świętu?

- Jakie wtedy dominują kolory?

- Kiedy obchodzimy to święto?

- Co to jest Boże Narodzenie / Wielkanoc?

Pomimo że ankieta (zdaniem niektórych badaczy) wymusza na dzieciach repliki „odpowiadające schematom sztucznie wymyślonych pytań oraz sugestiom ankietera dotyczącym treści merytorycznych"30, sądzimy, że nie powstałyby tak bogate konceptualizacje pojęć, gdyby nie rozmowa „twarzą w twarz”, którą odbyłyśmy w trakcie zadawania pytań. Podzielamy zdanie Anety Załazińskiej j1 ${ }^{31}$ ż:

język działa tylko podczas rozmowy, to co dzieje się podczas rozmowy, a rozmowy z dzieckiem przede wszystkim, jest wciąż ,negocjowane, przetwarzane i kreowane" 32 .

Dlatego w przypadku, kiedy dialog wydłużał się, pomijałyśmy pewne aspekty tworzące strukturę kognitywną świąt. Kierowała nami myśl zapamiętana z Dociekań filozoficznych Ludwiga Wittgensteina odnosząca się do terminu „gry językowej”:

Gra językowa ma podkreślić, że mówienie jest częścią pewnej działalności [...], aby zrozumieć każdą wypowiedź, konieczny jest kontekst ${ }^{33}$.

W ten sposób pojmujemy dochodzenie do znaczenia wyrazu — poprzez jego użycie. Naszym zdaniem tylko w rozmowie/dialogu, dzięki ,wszechogarniającemu kontekstowi”, możemy dojść do znaczenia wyrazu. Takie postępowanie, jak nam się wydaje, jest pogodzeniem reguł pragmatycznych i semantycznych. Nie jest postępowaniem wbrew nakazowi Wittgensteina: ,,...] nie pytajcie o znaczenie, pytajcie o użycie" ${ }^{34}$, ponieważ każde użycie ma swojego użytkownika, a każdy użytkownik świadomie uwydatnia subiektywny punkt widzenia, który dzięki kontekstowi oddaje pewien sposób widzenia świata przez mówiącego.

${ }^{30}$ B. Boniecka: Dziecięce wyobrażenie świata. Zbiór studiów. Lublin 2010, s. 76.

${ }^{31}$ A. Załazińska: Niewerbalna struktura dialogu. W poszukiwaniu polskich wzorców narracyjnych i interakcyjnych zachowań komunikacyjnych. Kraków 2006, s. 18.

32 Ibidem.

${ }^{33}$ L. Wittgenstein: Dociekania filozoficzne. Tłum. B. Wolniewicz. Warszawa 1972, s. 20. Podkr. - U.J., N.P.

${ }^{34}$ Ibidem. 
Powstająca $\mathrm{w}$ ten sposób $\mathrm{w}$ umyśle [dziecka - U.J., N.P.] wiedza ma charakter dialogowy, dynamiczny [...], głęboko penetruje doświadczenie rzeczywistości przez jednostkę i daje prawo do własnego rozumienia świata $^{35}$.

Ponadto przekonał nas kierunek myślenia Heleny Borowiec, która stwierdziła:

Oczywiste jest, że zadawane dziecku pytania nadają kierunek jego rozumowaniu i skłaniają je do systematyzowania swej wiedzy w określony sposób. Jednak odpowiedź jest oryginalnym wytworem myślenia dziecka. Ani bowiem rozumowanie prowadzące je do odpowiedzi, ani wiedza wykorzystywana przez dziecko w czasie jego refleksji nie pozostają pod bezpośrednim wpływem eksperymentatora (pytającego). Dziecko nie jest jedynie istotą naśladowczą. [...] W tym sensie nawet to, co zostało zasugerowane przez dorosłego, staje się do pewnego stopnia oryginalnym wytworem dziecka ${ }^{36}$.

Zebrany materiał badawczy zestawiłyśmy z definicjami ze Słownika języka polskiego ${ }^{37}$. Uzyskane od dzieci odpowiedzi stały się jakościowymi charakterystykami świąt $\mathrm{w}$ ramach aspektów (w artykule używamy zamiennie terminów aspekt, podkategoria, faseta) sugerowanych pytaniami szczegółowymi. Zadając pytania, chciałyśmy ustalić sposób porządkowania wiedzy oraz językowe sposoby jej werbalizacji. Zgodnie z metodologią kognitywną, przypatrując się bazie semantycznej interpretowanych wyrazów, możemy bowiem wnioskować o rodzaju wiedzy (potocznej, naukowej) i typie racjonalności (zdroworozsądkowej, naiwnej), przywoływanej podczas charakterystyki przedmiotu. Wykorzystując zgromadzone fakty językowe, dążymy do zrekonstruowania modelu definicji kognitywnej opisywanych świąt. W artykule postaramy się zaprezentować, które komponenty „ramy doświadczeniowej” oraz cechy interpretowanych wyrazów zostały uznane przez dzieci za szczególnie ważne, podczas charakterystyki wymienionych w tytule artykułu pojęć. Posługując się pojęciem fasety (aspektu, podkategorii), nawiązujemy tym samym do opisu semantycznego Wierzbickiej ${ }^{38}$, w którym oznacza ono grupę klas odpowiadających jakiejś wspólnej charakterystyce.

Wydaje nam się, że przeprowadzone rozmowy były czymś w rodzaju „wsłuchiwania się" w dziecięce rozumienie świata, swoistym negocjowaniem znaczeń utrwalonych w kulturze i w fazie końcowej - ich twórczym rekon-

\footnotetext{
${ }^{35}$ Światy dziecięcych znaczeń. Red. D. Klu s-Stańska. Warszawa 2004, s. 24.

${ }^{36}$ H. Borowiec: Dziecięce rozumienie świata (studium lingwistyczne). Lublin 2014, s. 276.

${ }^{37}$ https://sjp.pwn.pl/ [data dostępu: 22.01.2018].

38 A. Wierzbicka: Lexicography and Conceptual Analysis. Ann Arbor 1985.
} 
struowaniem $^{39}$. Zarówno podczas zbierania materiału, jak również w analizie końcowej interesował nas zakres wiedzy, jej rodzaj — potoczny, szkolny, naukowy - oraz typ doświadczeń, które wspólnie zadecydowały o wyjaśnieniu istoty badanych pojęć.

\section{Materiał badawczy}

W Słowniku języka polskiego możemy znaleźć następujące definicje „Bożego Narodzenia” oraz „Wielkanocy”:

Boże Narodzenie — święto obchodzone przez chrześcijan na pamiątkę narodzenia Chrystusa ${ }^{40}$.

Wielkanoc - święto kościelne obchodzone przez chrześcijan na pamiątkę zmartwychwstania Chrystusa, w niedzielę po pierwszej wiosennej pełni Księżyca ${ }^{41}$.

Opis językowego obrazu fragmentu rzeczywistości odnoszącego się do Bożego Narodzenia jest bardzo ciekawy. Odwzorowanie dziecięcej świadomości językowej poprzez zastosowanie definicji otwartej, która uwzględnia w opisie różny stopień utrwalenia cech, od tych bardziej charakterystycznych do jednostkowych i okazjonalnych ${ }^{42}$, pozwala na ujęcie definiowanego święta w następujące kategorie semantyczne:

\section{Kategoria nadrzędna (genus proximum)}

Pierwszą i najważniejszą kategorią, którą wyodrębniłyśmy, jest kategoria nadrzędności. Z uzyskanych eksplikacji wynika, że jedynie ośmioro dzieci potrafi zaliczyć Boże Narodzenie do kategorii nadrzędnej jako: święto (6) ${ }^{43}$ lub uroczystość (2). Jedno dziecko powiedziało, że: jest to po prostu takie coś, a następnie od razu przeszło do opisu czynności wykonywanych w tym okresie. Podobnie było w wypowiedziach pozostałych ankietowanych. Zabrakło w nich

${ }^{39}$ M. Wiśniewska-Kin: „Miłość jest jak wiatrak” — czyli o poznawczej naturze metafor dziecięcych. Łódź 2009, s. 22.

${ }^{40} \mathrm{https}: / /$ sjp.pwn.pl/szukaj/Bo\%C5\%BCe\%20Narodzenie.html [data dostępu: 22.01.2018].

${ }^{41} \mathrm{https}$ ://sjp.pwn.pl/szukaj/Wielkanoc.html [data dostępu: 22.01.2018].

42 J. Bartmiński: Definicja kognitywna jako narzędzie opisu konotacji. W: O definicjach i definiowaniu..., s. 169-183.

${ }^{43}$ Liczby w nawisach oznaczają liczbę odpowiedzi. 
kategorii nadrzędnej, a pojawiały się opisy podejmowanych działań, np.: dzielimy się opłatkiem; idziemy do kościoła. Dzieci znały jednak istotę tego święta, gdyż mówiły, że wtedy Chrystus się narodzit (6).

$\mathrm{Z}$ zestawienia definicji słownikowej $\mathrm{z}$ wypowiedziami dziecięcymi wynika, że ankietowani zaliczyli Boże Narodzenie do kategorii nadrzędnej. Potrafili także określić istotę tego święta i pamiątkę, którą wtedy obchodzimy — narodziny Chrystusa. W eksplikacjach dzieci zabrakło jedynie podkreślenia, że jest to święto kościelne.

Opisy Wielkanocy dowodzą, że dziewięcioro dzieci zaliczyło to święto do kategorii nadrzędnej, dodając, że wtedy zmartwychwstat Pan Jezus (5), a jedna osoba podkreśliła, że jest to bardzo ważne święto. Pojawiło się także określenie Wielkanocy jako „okresu świętowania, gdy świętuje się Triduum Paschalne i Zmartwychwstanie Jezusa" (1). Dwie osoby odpowiedziały, że jest to taki czas, obchodzony na pamiątke zmartwychwstania Jezusa. Pozostali ankietowani (6) nie potrafili zaliczyć Wielkanocy do kategorii nadrzędnej, lecz od razu przechodzili do opisu czynności związanych z tą uroczystością, np.: dzielenie się jajkiem czy chodzenie do kościoła.

\section{Wykonywane czynności}

Kolejną wyodrębnioną kategorią są czynności wykonywane podczas trwania Bożego Narodzenia. Zadając to pytanie, chciałyśmy sprawdzić, jak wygląda celebracja tego święta u każdego $\mathrm{z}$ ankietowanych. $Z$ uzyskanych eksplikacji można wyodrębnić bardzo podobny schemat działań. Po przygotowaniu uroczystej kolacji dzieci wypatruja pierwszej gwiazdki (3). Następnie rozpoczyna się świętowanie wigilii Bożego Narodzenia. U większości ankietowanych przed przystąpieniem do jedzenia czytane jest Pismo Św. (6) i odmawiany jest pacierz (4). Po zakończeniu tych czynności następuje dzielenie się opłatkiem (15), któremu towarzyszy sktadanie sobie wzajemnie życzeń (8). Dopiero wówczas można zasiaść do stołu, by skosztować wszystkich potraw (7). Po kolacji następuje, zdaniem dzieci, najciekawsza część wieczoru, bowiem rozpakowywane sq prezenty znajdujace się pod choinka (9). Dodatkowo ankietowani wskazali na śpiewanie kolęd (9), a siedem osób wspomniało, że o północy wraz z rodzina udaja się na Pasterkę, aby móc się pomodlić. Dwoje dzieci przywołało zwyczaj panujący w ich domach, polegający na wtożeniu sianka pod obrus, dodając, że jest to konieczne, aby Bóg mógt się tam narodzić.

Z otrzymanych eksplikacji wynika, że dziesięcioletnie dzieci znają schemat postępowania podczas obchodzenia Bożego Narodzenia. Nie są im obce zwyczaje i obrzędy charakterystyczne dla tego święta. Zwracają uwagę na te czynności, które są wpisane na stałe w obrzęd świąt, są to tzw. zachowania symboliczne $^{44}$, a mianowicie: dzielenie się opłatkiem, składanie sobie życzeń,

\footnotetext{
${ }^{44}$ B. Niesporek-Sza mburska: Językowy obraz pór roku..., s. 158.
} 
oczekiwanie na pierwszą gwiazdkę oraz wkładanie sianka pod obrus. Ponadto uczniowie zauważają, że kolacja wigilijna ma uroczysty, podniosły i religijny charakter, podkreślany przez: czytanie Pisma Świętego, odmawianie pacierza oraz chodzenie na pasterkę. W swoich eksplikacjach zwracają uwagę na jeszcze inny wymiar świąt - obdarowywanie. Dla badanych to jeden z najbardziej typowych elementów rytuału świątecznego ${ }^{45}$. W zasadzie dzieci wymieniły wszystkie najważniejsze czynności, składające się na obrzęd Wigilii Bożego Narodzenia, pominęły tylko św. Mikołaja jako darczyńcę prezentów.

\section{Czynności wykonywane podezas świąt Bożego Narodzenia}

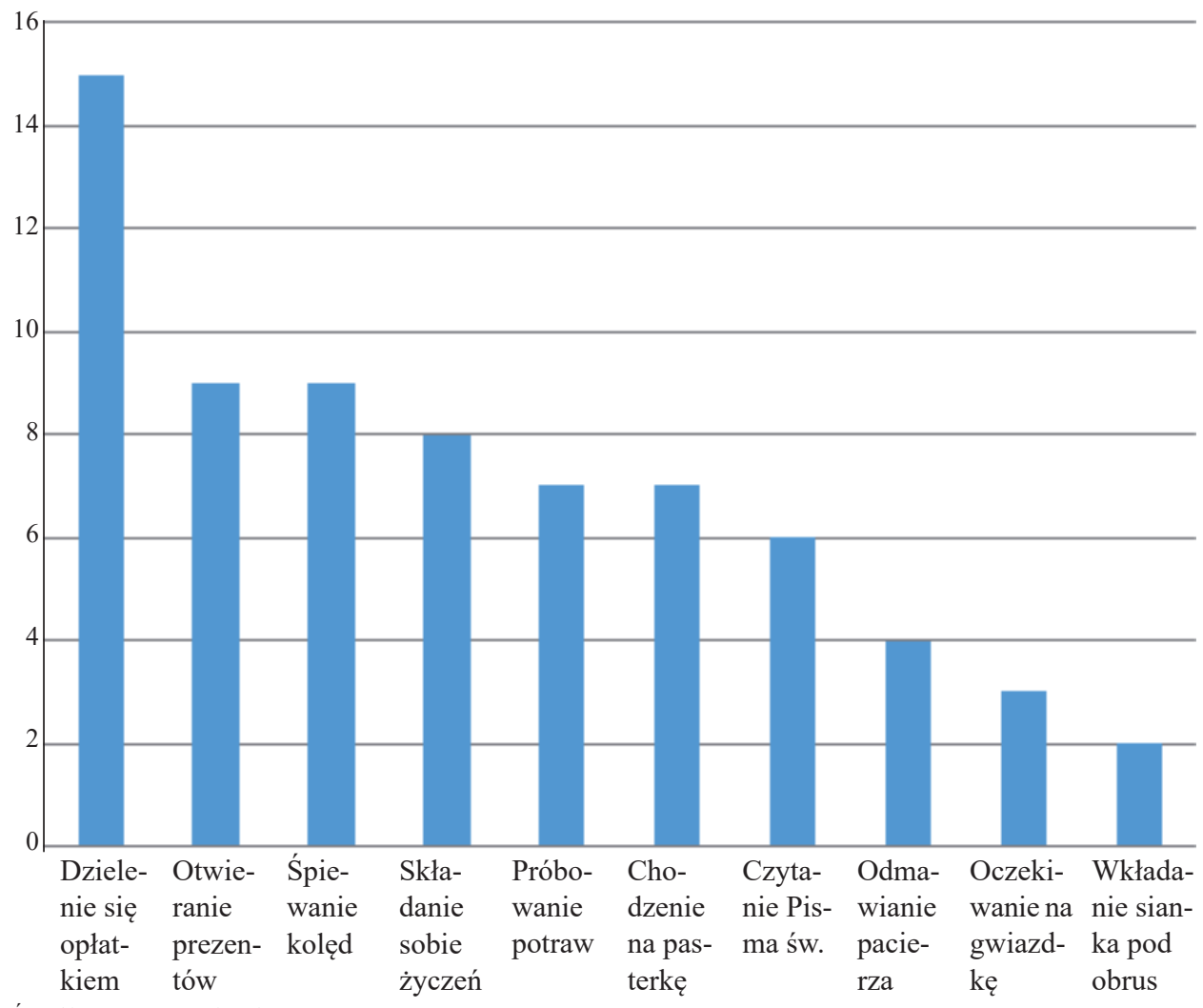

Źródło: Opracowanie własne.

Z pozyskanych eksplikacji da się również określić działania podejmowane w okresie Wielkanocy, choć często badani wskazywali na podobny schemat czynności. Najwięcej osób odpowiedziało, że święcimy wtedy pokarmy (12), dodając, że ma to miejsce $w$ Wielka Sobotę (9). Na drugim miejscu znalazło się

\footnotetext{
45 Ibidem, s. 166.
} 
dzielenie się jajkiem (10), któremu towarzyszy (zdaniem pięciorga dzieci) składanie sobie życzeń. Większość osób wskazała także, że podczas świąt wielkanocnych chodzimy do kościoła (9), dopowiadając, że w Wielka Niedzielę msza ta zwana jest Rezurekcja (5), którą jedna z dziewczynek opisała: msza rezurekcyjna rozpoczyna się od procesji. Sypie się wtedy kwiatki, nosi obrazy i poduszeczki ${ }^{46}$. Jedno dziecko wyjaśniło, że przychodzac do domu po tej uroczystej mszy, mówimy: „Pan Jezus zmartwychwstat!”, a ktoś kto został w domu powinien odpowiedzieć: „Prawdziwie zmartwychwstat!”. W ośmiu wypowiedziach wskazane są następujące czynności: zasiadamy do stołu, jemy uroczyste śniadanie wielkanocne, które — zdaniem jednego dziecka — powinno potrwać dlugo, oraz modlimy się (2). Pozostałe repliki to: szukamy prezentów od zajączka (3), z zaznaczeniem przez jedną osobę, że u mnie $w$ domu tak się nie robi; adorujemy krzyż $w$ Wielki Piątek (2). Tylko jeden ankietowany zwrócił uwagę na miły zwyczaj, uwielbiany zwłaszcza przez dzieci: w Lany Poniedziałek oblewamy sie woda.

Analiza zebranego materiału wskazuje, że badana grupa dzieci wie, jakie czynności towarzyszą Wielkanocy. Potrafią one wskazać zarówno świeckie zwyczaje, np. szukanie prezentów od zajaczka, jak i zwyczaje religijne — chodzenie do kościoła, modlitwa. Zebrane wypowiedzi są z pewnością świadectwem uczestnictwa badanych dzieci w obchodach świąt wielkanocnych.

\section{Czas obchodzenia świąt}

Następną kategorią opisującą Boże Narodzenie jest czas rozpoczęcia świąt. Zadając pytanie na ten temat, chciałyśmy sprawdzić, czy dzieci potrafią umiejscowić uroczystość Bożego Narodzenia w odpowiednim dniu i miesiącu. Pytanie to sprawiło dzieciom najwięcej trudności. Błędem, który popełniali ankietowani, było utożsamianie dnia obchodzenia Wigilii z celebracją Bożego Narodzenia: 24 grudnia (4). Dwoje rozmówców od razu wskazało, że to trudne pytanie, nie pamiętam, a jedna osoba odpowiedziała: 22 grudzień. Pięcioro ankietowanych trafnie podało miesiąc grudzień, lecz nie potrafiło doprecyzować konkretnego dnia, mówiąc: nie pamiętam dokładnie którego. Jedynie troje dzieci udzieliło właściwej odpowiedzi, że 24 grudnia obchodzimy Wigilię, a Boże Narodzenie jest 25 grudnia.

Poddając analizie otrzymane eksplikacje, można wysnuć wniosek, że data obchodzenia świąt Bożego Narodzenia nie została jeszcze trwale zapisana w umysłach dziesięcioletnich dzieci. Może to być spowodowane utożsamieniem Bożego Narodzenia z obchodzoną dzień wcześniej Wigilią lub niemożnością zapamiętania precyzyjnie dnia, przy trafnym wskazaniu miesiąca.

46 Zwyczaj sypania kwiatów oraz noszenia obrazów jest charakterystyczny dla procesji związanej ze świętem Bożego Ciała. W trakcie mszy rezurekcyjnej połączonej z poranną procesją niesiona jest hostia w monstrancji, krzyż procesyjny ozdobiony czerwoną stułą oraz figurka Jezusa Zmartwychwstałego. Wydawać się zatem może, że dziecko utożsamia zwyczaje związane z dwoma różnymi świętami. 
Czas obchodzenia świąt Bożego Narodzenia

Wykres 2

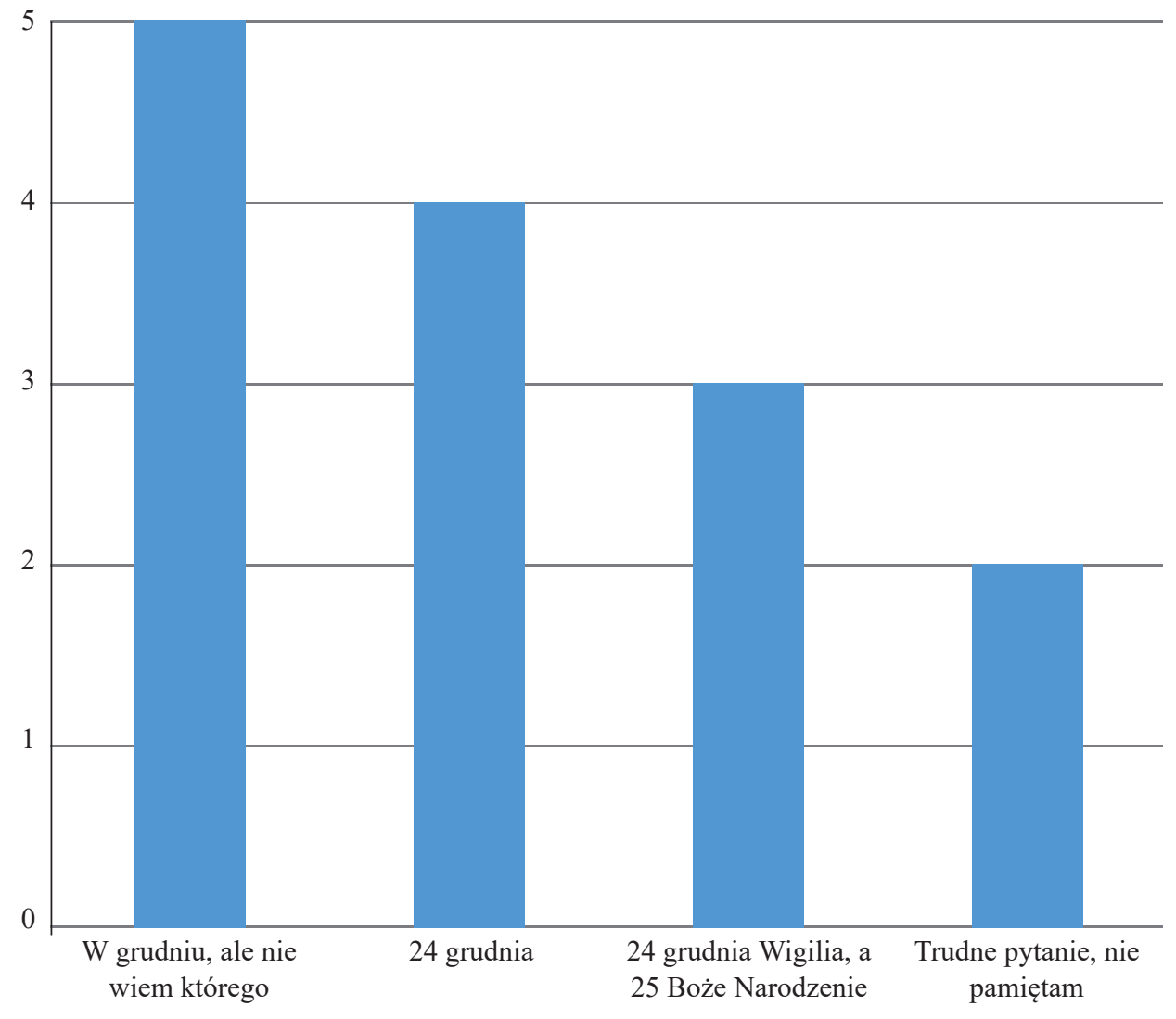

Źródło: Opracowanie własne.

Pomimo że Wielkanoc jest świętem ruchomym, również zadałyśmy pytanie dotyczące czasu świętowania w celu sprawdzenia, czy dzieci potrafią wskazać miesiące, w których święta Wielkanocy mogą być obchodzone.

Dziecięce eksplikacje ujawniają, że pytanie dotyczące daty sprawiło ankietowanym dużą trudność. Tylko trzy osoby trafnie odpowiedziały: tak naprawdę nie ma konkretnej daty, dwie zaś dodały, że Wielkanoc wypada czasem w marcu, czasem w kwietniu, zależy od roku. Miesiąc kwiecień wskazały cztery osoby, a marzec - dwie. Trójka ankietowanych w odpowiedzi na zadane pytanie wskazała datę, więc: 14, 15, 16 i 17 kwietnia (w te dni przypadała Wielkanoc w roku przeprowadzenia ankiety). Kolejne trzy osoby, chyba nie do końca zrozumiały pytanie, gdyż stwierdziły, że Wielkanoc obchodzimy $w$ niedziele (2) i $w$ Wielka Sobotę (1), a gdy poprosiłyśmy o doprecyzowanie daty, dodały, że nie wiedza. 


\section{Data obchodzenia Wielkanocy}

Wykres 3

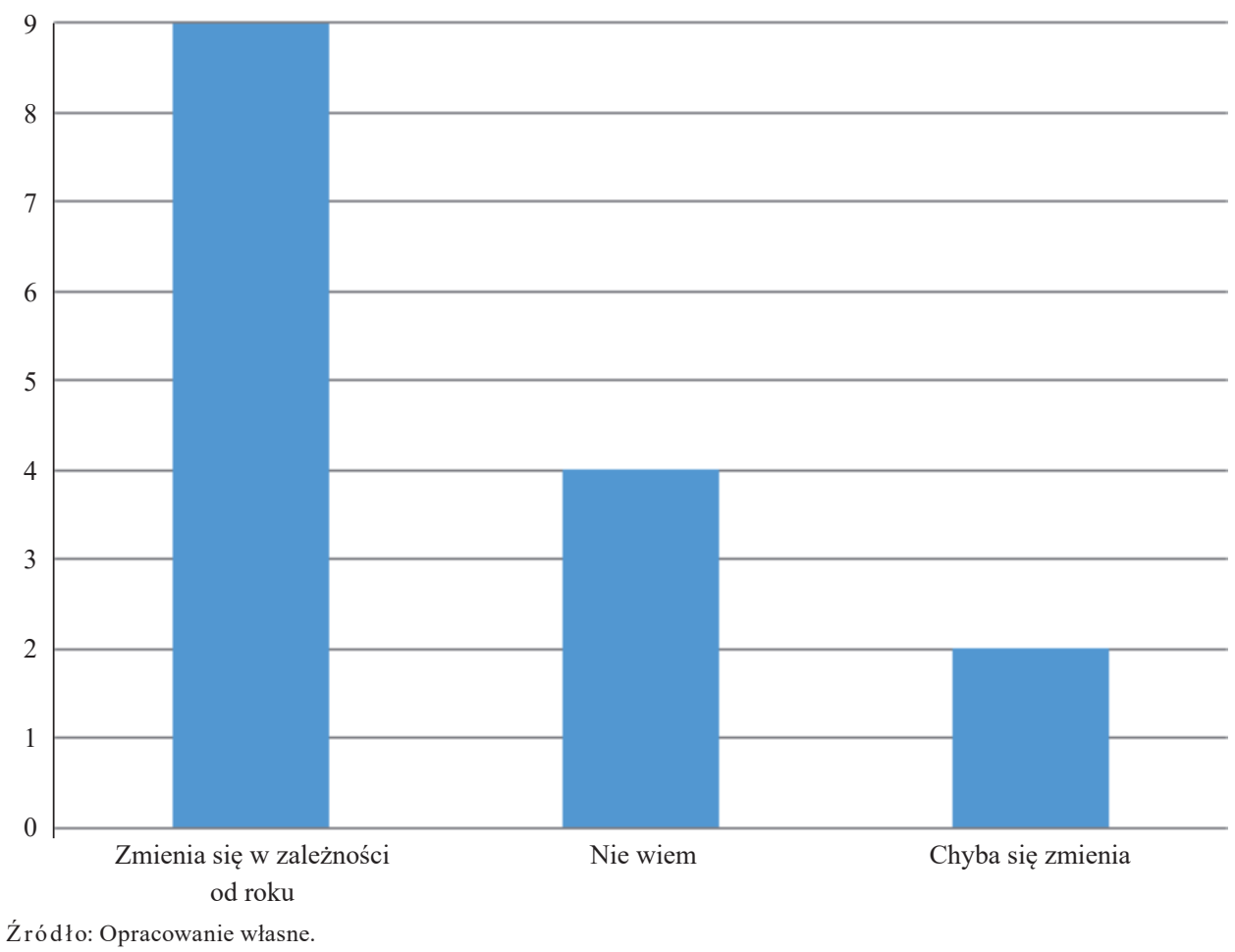

Uzyskany materiał upoważnia do stwierdzenia, że badane dzieci mają trudność ze wskazaniem daty obchodzenia Wielkanocy: w marcu i kwietniu. Większość zdaje sobie sprawę z tego, że jest to święto ruchome, obchodzone każdego roku z inną datą.

\section{Kolory}

Kolejnym wyróżnionym aspektem są kolory charakterystyczne dla świąt Bożego Narodzenia. Chciałyśmy sprawdzić, jakie barwy, zdaniem ankietowanych, dominują podczas tych dni. Z uzyskanych eksplikacji wynika, że większość dzieci kierowała się skojarzeniami związanymi z bożonarodzeniową symboliką oraz porą roku. Najwięcej rozmówców wskazało na kolor biały (10), a osiem osób dodało, że to z uwagi na fakt, że biały jest kolorem śniegu i zimy. $\mathrm{Na}$ drugim miejscu znalazł się kolor zielony (8), który został powiązany $\mathrm{z}$ choinką przystrajaną w domach $\mathrm{w}$ okresie Bożego Narodzenia. W pozostałych odpowiedziach dzieci wskazały kolory: złoty (2), niebieski (2) i czerwony (5), ponieważ: to taki cieply kolor (1) oraz dlatego, że zazwyczaj znajduje się na 
lampkach choinkowych (1). Dwóch ankietowanych stwierdziło: wtedy jest bardzo kolorowo.

\section{Kolory kojarzone z Bożym Narodzeniem}

Wykres 4

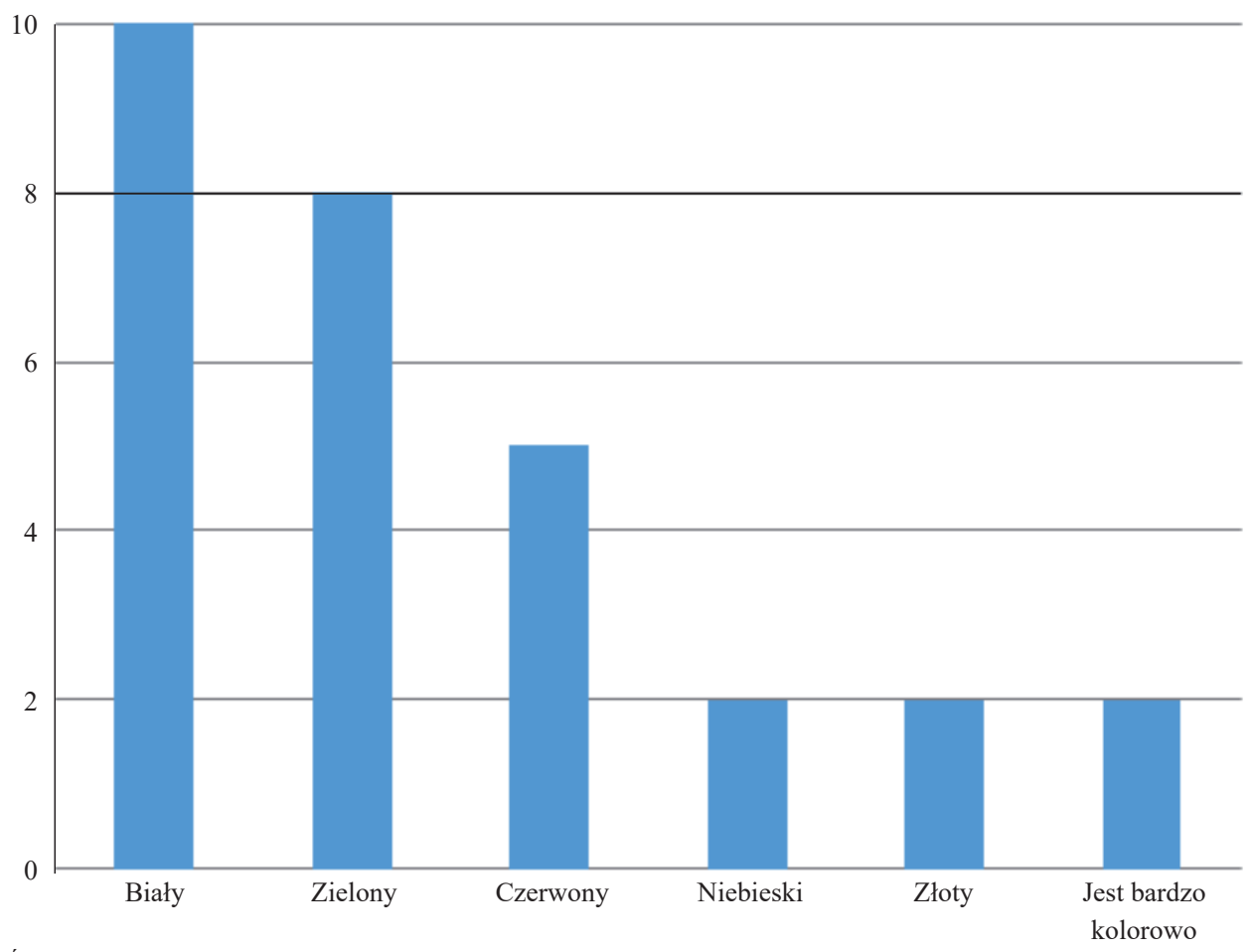

Źródło: Opracowanie własne.

Na podstawie uzyskanego materiału można stwierdzić, że dzieci świetnie potrafią powiązać Boże Narodzenie z charakterystycznymi dla niego barwami. Wiąże się to z bogatymi doznaniami zmysłowymi badanych oraz świadczy o ich rozbudowanej wyobraźni i umiejętności kojarzenia, która wymaga udziału skomplikowanych procesów myślowych.

Podobne uogólnienia można sformułować na podstawie wypowiedzi dzieci o kolorach charakterystycznych dla okresu wielkanocnego. Dzieci kojarzą Wielkanoc z kolorem żóltym (11) i zielonym (10). Część ankietowanych dopowiedziała, że są to takie wiosenne kolory (6). W innych wypowiedziach wymieniono: czerwony (5), pomarańczowy (2), biały (1) oraz brazowy (1). Jedna z osób uzupełniła, że są to kolory tęczowe, tak jak na pisankach.

Zdecydowana większość badanych wskazała na kolory żólty i zielony, które są powszechnie kojarzone ze świętami Wielkanocy oraz wiosną. W naszej kulturze i tradycji Wielkanoc to święto zmartwychwstania, odrodzenia życia, 
wiosny. Świętu towarzyszy zatem określona paleta barw, przede wszystkim: biel, żółć oraz zieleń. Kolor zielony symbolizuje nowy początek życia, jednoznacznie wiąże się z wiosną. Biały to oznaka czystości i niewinności. Tego koloru są wielkanocne baranki i zajączki. Z kolei w symbolice kościelnej biel jest kolorem ofiary (zmartwychwstały Jezus ukazywany jest zazwyczaj w białej szacie), zieleń zaś to kolor odrodzenia. Barwa żółta symbolizuje radość, optymizm, dobrą energię, a także nowe życie. Na wielkanocnym stole zwykle pojawiają się wiosenne bukiety żółtych żonkili lub tulipanów, niekiedy doniczki z krokusami czy gałązki forsycji. Może nieco dziwić, że dzieci przywołały również kolor czerwony; był on też wymieniany (również przez pięcioro dzieci) podczas rozmów o Bożym Narodzeniu. Wydaje się, że w czasie Wielkanocy jedynym czerwonym akcentem jest stuła, zdobiąca krzyż procesyjny niesiony podczas porannej rezurekcji.

Wykres 5

Kolory kojarzone z Wielkanocą

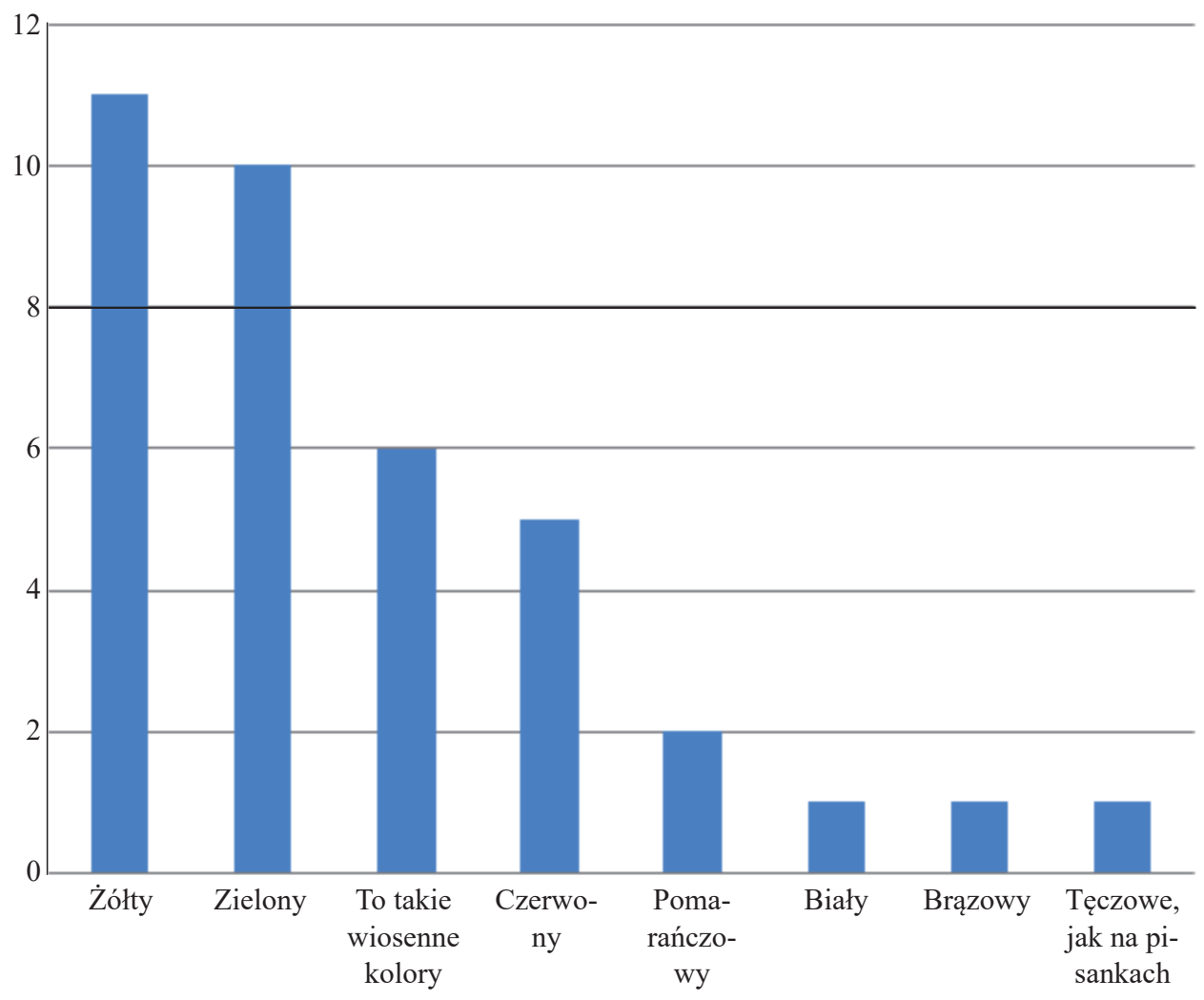

Źródło: Opracowanie własne. 


\section{Nastrój}

Następną wyodrębnioną podkategorią jest nastrój panujący w czasie świąt Bożego Narodzenia. Wypowiedzi badanych przynoszą informacje o ich odczuciach związanych ze świętami. Według dzieci jest to czas bardzo przyjemny i pozytywny. Najwięcej osób wskazało, że jest wtedy wesoło (13), jedna osoba dodała, że to dlatego, że Chrystus się wtedy narodził. Pozostałe wskazania są następujące: nastrój jest wtedy radosny (5), szczęśliwy (4), rodzinny (2) i spokoj$n y$ (2). Dwoje dzieci wskazało na rodzinny charakter świąt. Pojawiły się i takie odpowiedzi: podczas świąt Bożego Narodzenia czuć taka magię w powietrzu (2). $\mathrm{Na}$ szczególną uwagę zasługuje metaforyczne wyrażenie - magia $w$ powietrzu $u^{47}$. Być może dzieci słyszały, jak dorośli życzą sobie magicznych świąt czy też magicznego czasu.

\section{Nastrój towarzyszący Bożemu Narodzeniu}

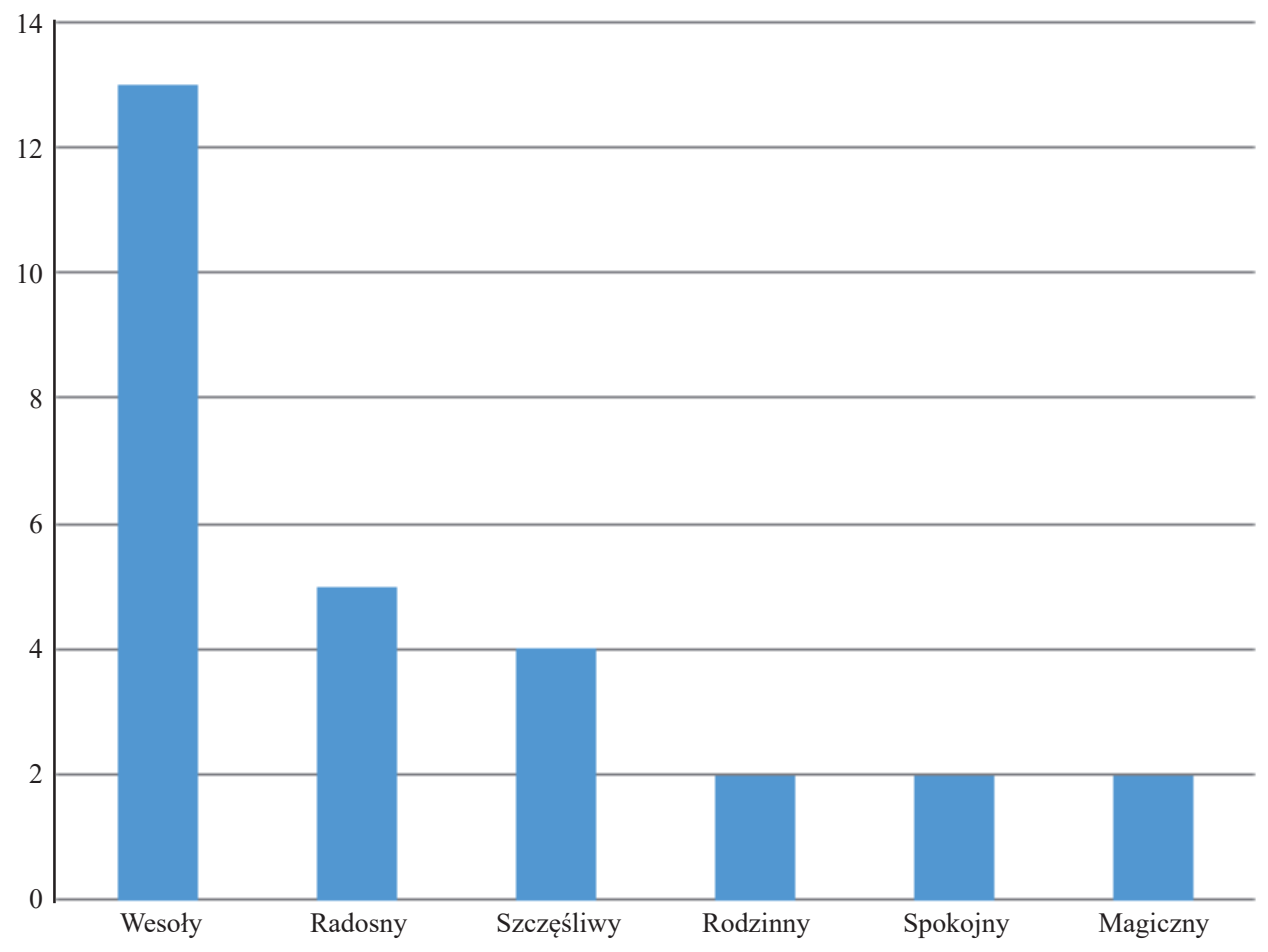

Źródło: Opracowanie własne.

${ }^{47}$ Należy zwrócić uwagę, że tego typu wyrażenie — metafora „magia świąt” — pojawia się często w programach telewizyjnych emitowanych w okresie świątecznym, zatem można by sądzić, że w konceptualizacji dziecka jest ona wtórna. 
Poddając analizie pozyskany materiał, można wysnuć wniosek, że Boże Narodzenie kojarzy się dzieciom bardzo pozytywnie. Według ankietowanych jest wtedy wesoło, spokojnie i magicznie. Badani wskazują na rodzinny charakter świąt, co budzi w nich miłe skojarzenia.

Nastrój, jaki towarzyszy Wielkanocy, jest również pozytywny, związany z emocjami, które są udziałem dzieci. Najwięcej ankietowanych wskazało, że jest on wesoty (6) i radosny (4), dodając jako powód, że Jezus Chrystus wtedy zmartwychwstat (2). W innych wypowiedziach badani określali nastrój jako: mity (2), rodzinny (2), uroczysty (2) oraz szczęśliwy, bo wszyscy się ciesza, że Jezus zmartwychwstat (1). Dużą wiedzą na temat święta oraz „dorosłą" postawą wykazała się dwójka dzieci. Zauważyły one, że nastrój zależy od dnia, w ciagu Triduum Paschalnego jest on smutny, a w Niedzielę Wielkanocna radosny.

\section{Symbole}

Kolejną ważną podkategorią są symbole, które kojarzą się dziesięciolatkom z Bożym Narodzeniem. Pytanie odnoszące się do symboli uruchomiło bardzo bogatą ścieżkę kognitywną. Dzieci odpowiadały chętnie i wyczerpująco. Najwięcej z nich wskazało na choinkę (10) oraz szopkę bożonarodzeniowa (7).

Symbole Bożego Narodzenia

Wykres 7

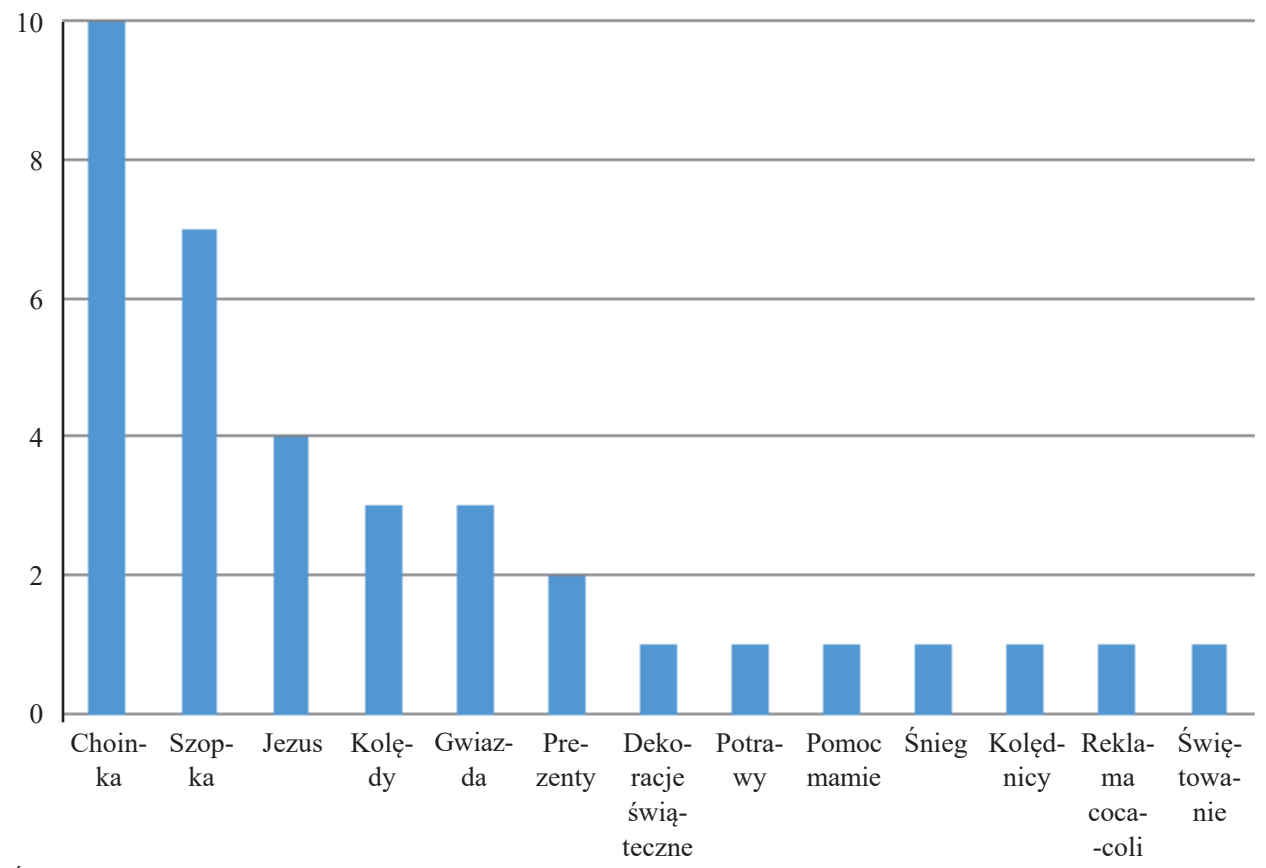


Badani wymienili też: gwiazdę (3), kolędy (3) oraz kolędników (1), prezenty (2), dekoracje świateczne (1), potrawy (1). Nie zabrakło skojarzeń odnoszących się do: czynności związanych z przygotowaniem do świąt - będę pomagać mamie w szykowaniu potraw (1); opadów atmosferycznych charakterystycznych dla zimy — śnieg (1); samej istoty święta — narodziny Jezusa (4). Jedno dziecko wskazało na komercyjny aspekt świąt Bożego Narodzenia, odpowiadając, że wiążą się one z reklama coca-coli, która zawsze leci wtedy w telewizji. Odnotowano także bardzo nietypową odpowiedź: mi Boże Narodzenie kojarzy się ze świętowaniem, że zbawienie przyszło na świat. Dziecko posłużyło się piękną metaforą: zbawienie przyszło na świat, być może zasłyszaną w kościele lub zapamiętaną z pieśni religijnych.

Zebrane wypowiedzi świadczą o tym, że święta Bożego Narodzenia są dzieciom doskonale znane i nie mają one trudności z przywołaniem symboli, które są dla nich charakterystyczne. Ich słownictwo w tym zakresie jest bardzo bogate, adekwatne i wielowymiarowe. Dziecięca perspektywa patrzenia na rzeczywistość odsłania także świąteczną kolekcję w postaci: choinki, szopki, kolęd, pierwszej gwiazdki, prezentów, dekoracji świątecznych.

Podkategoria opisująca Wielkanoc jest także rozbudowana. Zebrany materiał ukazał bardzo duży zbiór przedmiotów i zjawisk. Uzyskane eksplikacje upoważniają do sformułowania wniosku, że najwięcej ankietowanych jako symbole świąt wielkanocnych wskazało jajka (7) oraz baranka (8), dodając, że jest on symbolem Jezusa (2). W pozostałych replikach wymieniano: pisanki (5), prezenty od zajaczka (3), krzyż (3), bazie (2), kurczaki (1), koszyczek (1) oraz lany poniedziatek (1). Jedno dziecko odpowiedziało, że ten czas kojarzy mi się po prostu ze zmartwychwstaniem Jezusa. Zaskakujące było stwierdzenie jednego chłopca, który powiedział, że nic mu się z Wielkanoca nie kojarzy.

W obrazie Wielkanocy ważne miejsce zajmuje święconka — wielkanocny koszyczek. Z otrzymanych eksplikacji wynika, że wszyscy ankietowani jako element niezbędny wskazali sól (15). Na drugim miejscu znalazł się baranek (12) jako symbol tych świąt, a w pozostałych odpowiedziach wymieniono: chleb (11), jajka (8), pisanki (7), które jedno z dzieci uznało za obowiazkowe, kiełbasa (6), pieprz (6), wędlina (5) oraz chrzan (4). Badani wymieniali także typowe wielkanocne ciasto - babke (4) i element dekoracyjny koszyczka bazie (2).

W pojęciu Wielkanocy dziesięciolatki wskazują na świąteczną kolekcję: baranek, jajko, bazie, kurczaki, koszyczek. Tylko jedno dziecko wymieniło bardzo ważną podkategorię związaną ze świętem wielkanocnym - Triduum Paschalne: Wielkanoc jest wtedy, gdy świętuje się Triduum Paschalne. Analiza pozostałych wypowiedzi prowadzi do wniosku, że dzieci (13) zdają sobie sprawę $\mathrm{z}$ istnienia i wagi trzech dni poprzedzających Wielkanoc, potrafią też podzielić Triduum Paschalne na: Wielki Czwartek, Wielki Piatek $i$ Wielka Sobotę. Tylko dwie osoby początkowo stwierdziły, że nie wiedzą, o jakie dni chodzi, jednak 
po podpowiedzi, jedna z nich potrafiła już poprawnie wymienić kolejne dni, natomiast druga odrzekła: nadal nic nie przychodzi mi do głowy.

Wykres 8

Symbole wielkanocne

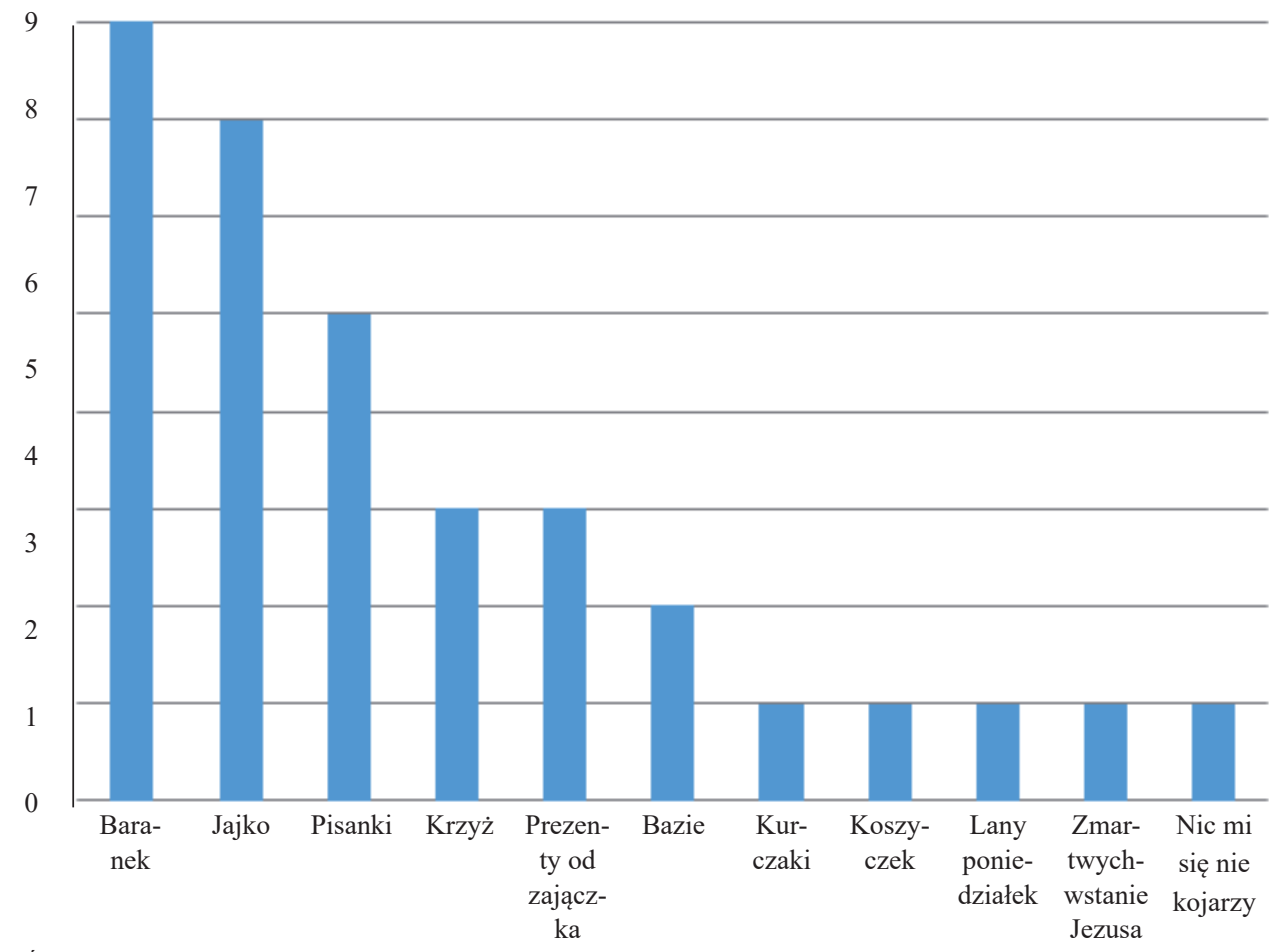

Źródło: Opracowanie własne.

Z otrzymanych eksplikacji wynika, że nie wszystkie dzieci potrafią scharakteryzować istotę oraz działania odnoszące się do kolejnych Wielkich Dni. Część badanych stwierdziła, że wtedy po prostu trzeba iść do kościoła (6), dodając, że idziemy tam, żeby się pomodlić (3), oraz że podczas tych dni czekamy już na święta (2). Pozostałe osoby, które wymieniły dni Triduum Paschalnego, potrafiły je także krótko scharakteryzować:

- Wielki Czwartek - jedynie czworo ankietowanych potrafiło określić istotę tego dnia, mówiąc, że wtedy obchodzimy pamiątkę ostatniej wieczerzy (2) oraz: wtedy Pan Jezus ustanowit Sakrament Eucharystii i Kaplaństwa (2). Pozostałe osoby wskazały, że wtedy idziemy do kościoła (2), przygotowujemy już różne sprawy w domu (1) i nie jemy już mięsa (1). Ciekawą, choć też zabawną z uwagi na przejęzyczenie, okazała się wypowiedź jednej z dziewczynek: wtedy ksiadz chowa opłatek do ciemnoty i zamiast dzwonków sq kołatki. 
— Wielki Piątek — tylko część dzieci ma jakąkolwiek wiedzę na temat czynności związanych z Wielkim Piątkiem. Jedynie dwie osoby potrafiły określić istotę tego dnia, mówiąc, że wtedy Pan Jezus umart na krzyżu. Jedno dziecko zwróciło uwagę, że powinniśmy się wtedy powstrzymać od pokarmów mięsnych. Pozostałe osoby dodały, że podczas nabożeństwa adorujemy krzyż Chrystusa (4).

- Wielka Sobota - większość dzieci Wielką Sobotę łączy z niesieniem do kościoła koszyczków, aby poświęcić jedzenie (11). Jednak tylko jeden uczeń zwrócił uwagę na religijny charakter Wielkiej Soboty, mówiąc, że wtedy Pan Jezus leży w grobie, inny dodał, że powinnyśmy czuwać przy grobie pańskim. Pojawiła się jeszcze replika wskazująca, że tego dnia malujemy jajka (1). Żadne dziecko nie wspomniało natomiast o wieczornym nabożeństwie, podczas którego następuje poświęcenie ognia i odnowienie przyrzeczeń chrzcielnych.

$\mathrm{Z}$ analizy uzyskanego materiału dotyczącego charakterystyki Triduum Paschalnego wynika, że prawie wszystkie dzieci potrafią wymienić jego kolejne dni, mają jednak trudności z opisaniem każdego z nich — wskazaniem, czego jest pamiątką oraz jakie zachowania religijne są z nim związane. Często odpowiadały ogólnikowo: powinno się iść wtedy do kościoła. Tego typu wypowiedzi mogą świadczyć o tym, że wiedza na temat Triduum Paschalnego nie jest jeszcze na trwale zapisana w umysłach dziesięciolatków bądź obyczaj związany $\mathrm{z}$ chodzeniem do kościoła $\mathrm{w}$ te dni nie jest praktykowany już tak powszechnie jak niegdyś.

\section{Przygotowania}

Kolejną wyróżnioną podkategorią są czynności, które wykonują ankietowani wraz ze swoimi rodzinami, aby przygotować się do świąt Bożego Narodzenia. $Z$ otrzymanych eksplikacji wynika, że najwięcej dzieci wskazało, że jest to ubieranie choinki (10), w tym troje dodało, że w ich domu odbywa się to: $d w a$ tygodnie przed świętami (1), dwa dni przed Wigilia (1) oraz $w$ Wigilię (1). Na drugim miejscu podano sprzątanie $w$ domu (9), a jeden z chłopców dopowiedział, że kilka dni przed świętami przyjeżdża ciocia, która pomaga mamie w świątecznych porządkach. Dzieci wymieniły też: przygotowywanie potraw (7) i ciast (3), przystrajanie domu ozdobami świątecznymi (2) oraz kupowanie prezentów dla bliskich (6). Jedna osoba odpowiedziała: tydzień wcześniej robimy duże zakupy, bo przecież musimy mieć z czego przygotowywać potrawy. W dniu Wigilii dzieci wskazały na przygotowywanie uroczystej kolacji (5) poprzez nakrycie do stołu (3), a jedno dziecko przywołało zwyczaj pozostawiania jednego pustego nakrycia dla zbłakanego wędrowca. Tylko dwie osoby zwróciły uwagę na duchowy charakter przygotowań do świąt Bożego Narodzenia, wskazując na chodzenie do kościoła (1) oraz przygotowanie się poprzez Adwent, czyli taki post, 
który trwa 4 tygodnie i jest oczekiwaniem na przyjście Pana Jezusa na świat. Wtedy co niedzielę $w$ kościele sq zapalane świece (1).

Wykres 9

\section{Czynności związane z Bożym Narodzeniem}

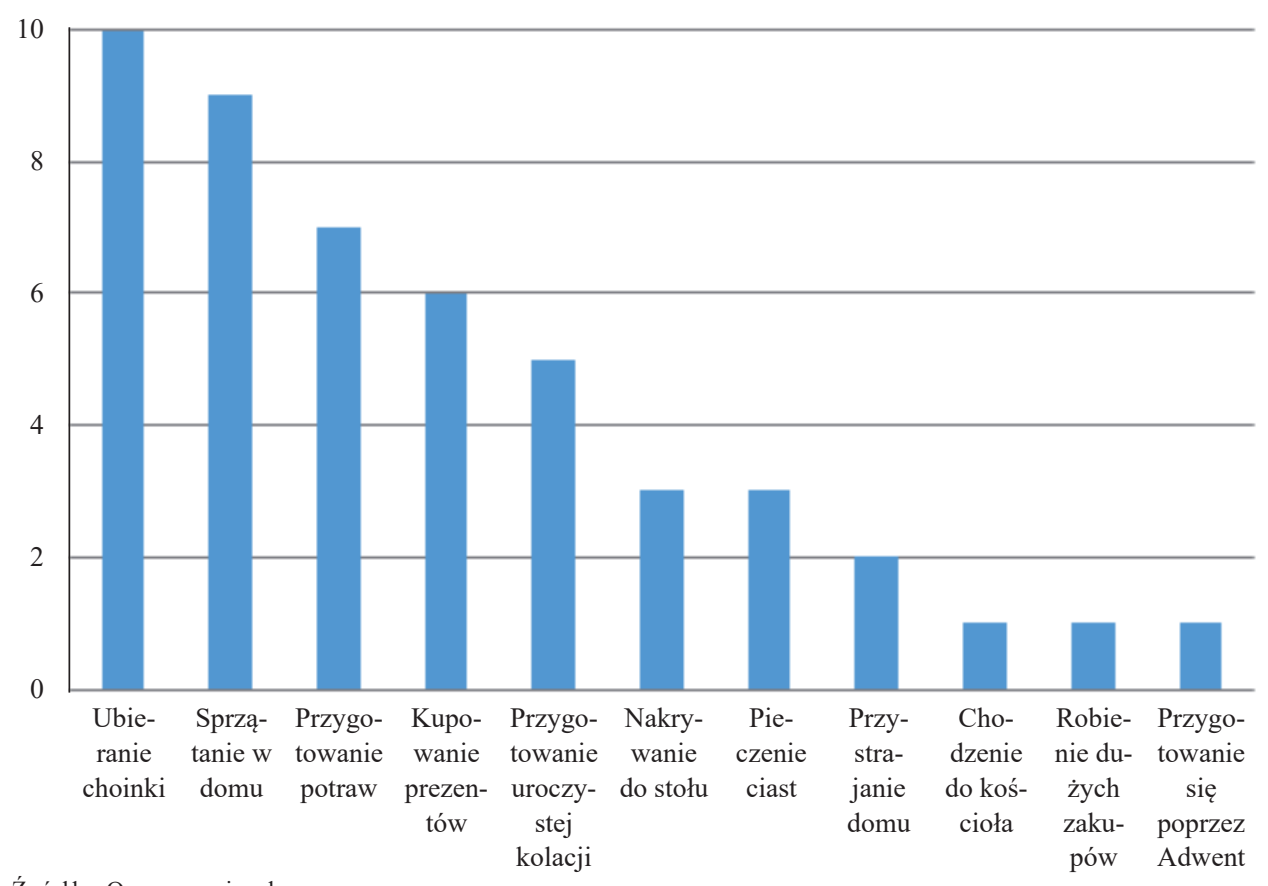

Źródło: Opracowanie własne.

Z uzyskanych eksplikacji można wywnioskować, że uczniowie znają z własnych doświadczeń i obserwacji charakter przedświątecznych dni, podporządkowanych głównie zajęciom domowym, budowaniu świątecznego nastroju poprzez sprzątanie i przyozdabianie domu oraz aranżację stołu. Tylko jedna osoba zwróciła uwagę na potrzebę duchowego przygotowania się do uczczenia narodzin Jezusa. Taka postawa może być konsekwencją dużej komercjalizacji świąt Bożego Narodzenia w środkach masowego przekazu i stopniowej rezygnacji części społeczeństwa $\mathrm{z}$ ich religijnego przeżywania.

Kolejną wyróżnioną fasetą są czynności, które wykonują ankietowani wraz ze swoimi rodzinami, aby przygotować się do świąt Wielkanocy. Z otrzymanych eksplikacji wynika, że najwięcej osób wskazało na malowanie jajek (7) i sprzatanie domu (7), m.in. dlatego, że na pewno przyjada do nas goście (1). Kolejni ankietowani stwierdzili, że przygotowują się do Wielkanocy, piekąc ciasta (6), gotując potrawy (5) i święcac koszyczki (3). Trzy osoby wykazały się bardzo dojrzałym sposobem myślenia oraz podejścia do rozmowy, oddając duchową istotę świąt Wielkanocnych: podczas Wielkiego Postu w piattki chodzę 
na drogę krzyżowa (3), a jedna z nich dodała, że wtedy możemy się tak kościelnie przygotować do Wielkanocy. Jedna dziewczynka przedstawiła zwyczaj, który przed tymi świętami jest celebrowany w jej domu: sadzi się owies, żeby uróst $i$ babcia stawia to $w$ doniczkach na stole. Pozostałe odnotowane repliki to: robienie dekoracji światecznych (1) oraz nakrywanie wcześniej do stotu (1). Jedno dziecko stwierdziło: u mnie w domu nie ma żadnych przygotowań.

\section{Czynności wykonywane podczas przygotowań do świąt wielkanocnych}

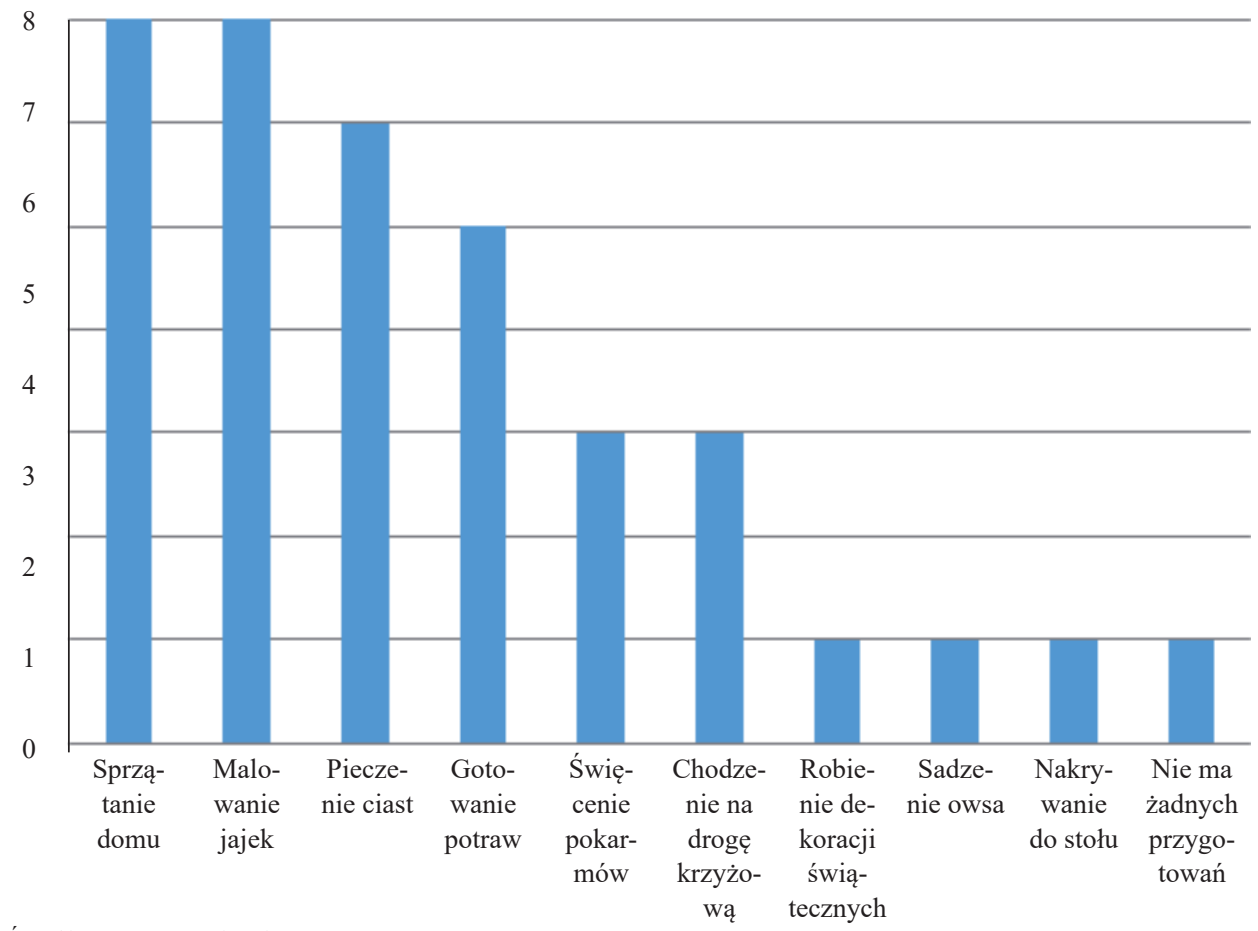

Źródło: Opracowanie własne.

Uzyskany materiał pozwala na sformułowanie wniosku, że dzieci dobrze orientują się w przygotowaniach, jakie należy poczynić przed świętami wielkanocnymi. Ścieżka kognitywna, która została przez nie stworzona, jest bogata i różnorodna - wymieniają one czynności zarówno „świeckie”, takie jak: sprzątanie, gotowanie, jak i „duchowe”, oddające prawdziwą istotę przygotowań: chodzenie do kościoła na drogę krzyżowa. W wypowiedziach tego typu odzwierciedlona została nie tylko wiedza badanych na temat wycinka rzeczywistości związanego z tradycją, obyczajami świątecznymi, a więc ich zakotwiczenie w kulturze ${ }^{48}$, lecz także dojrzałość języka.

48 Jeśli kulturę potraktujemy nie jako „,zjawisko materialne” zgodnie z tym, co pisał na ten temat Ward H. Goodenough w pracy z 1964 roku, ale jako „formę tego, co ludzie przechowują 


\section{Potrawy}

Ostatnia podkategoria dotyczyła potraw, które pojawiają się na wigilijnym stole. Aspekt ten obejmował dwa wymiary: liczbę potraw, które według tradycji powinny znaleźć się na stole, oraz przykłady dań.

Pytanie odnoszące się do liczby potraw okazało się trudne dla badanych. Z otrzymanych eksplikacji wynika, że pięć osób odpowiedziało, że wedtug tradycji powinno być 12 potraw, w tym jedno dziecko dodało: ale u mnie nie ma nigdy aż tylu. Trzy osoby stwierdziły, że nie ma na to żadnej reguly i to zależy ile, kto chce. Jeden rozmówca odrzekł wymijająco, że na pewno musi być dużo potraw, a kolejny wskazał na 8 dań. Pięć osób nie potrafiło udzielić odpowiedzi, przyznając: nie wiem (3) oraz nie pamiętam (2).

Wykres 11

Potrawy na wigilijnym stole

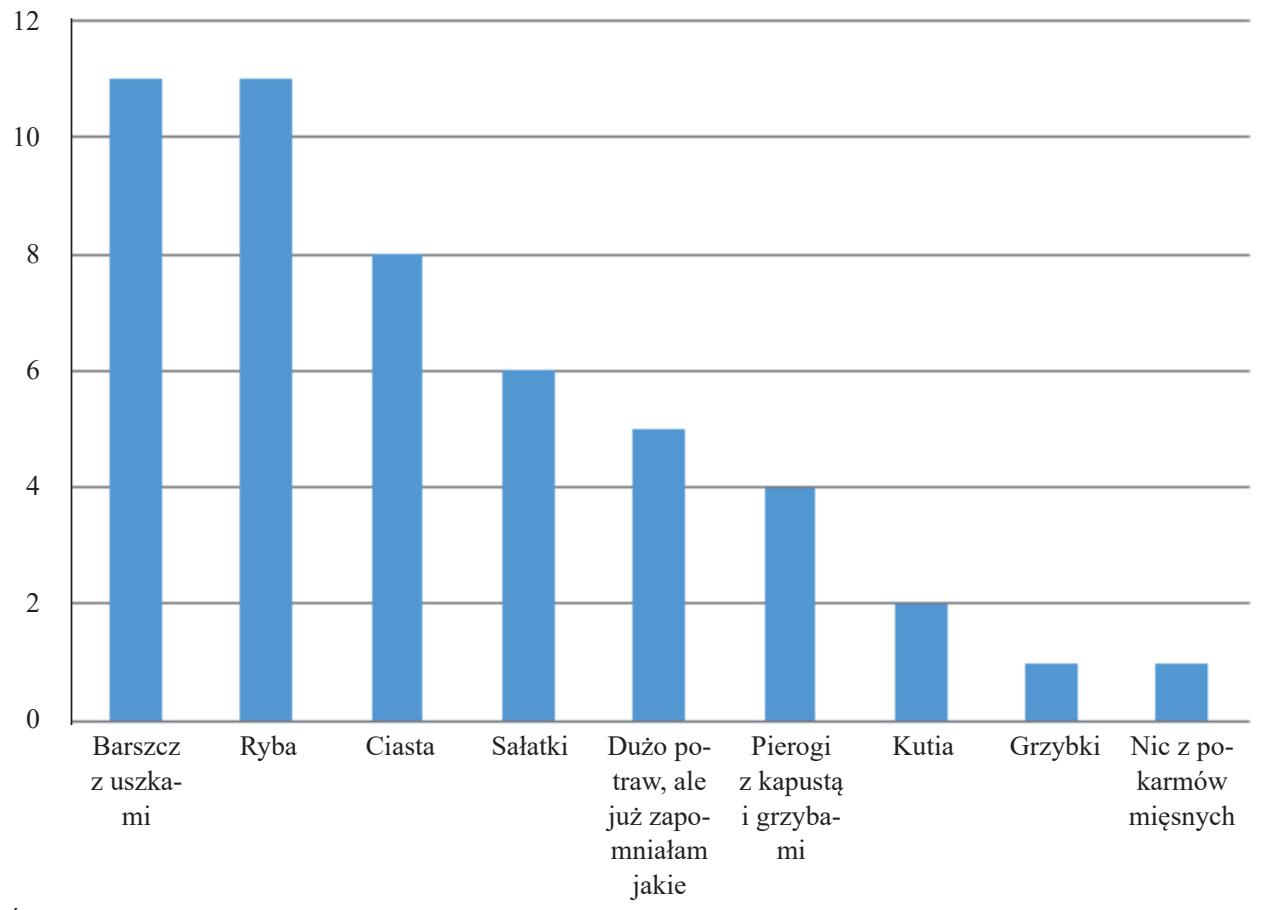

Źródło: Opracowanie własne.

w swoim umyśle, ich modeli postrzegania, kojarzenia i interpretowania świata" (za: M. Buchow ski, W.J. Burszta: Antropologia kognitywna: charakterystyka orientacji. W: Amerykańska antropologia kognitywna. Poznanie, język, klasyfikacja, kultura. Wybór i red. M. Buchowski. Warszawa 1993, s. 13), wówczas, w znaczeniu badanych wyrazów odnajdziemy „kulturowo zinterpretowany obraz świata" (R. Tokarski: Ramy interpretacyjne a problemy kategoryzacji (przyczynek do tak zwanej definicji kognitywnej). W: Językowa kategoryzacja świata..., s. 18), który jest wyraźnie akcentowany w pracach badaczy językowego obrazu świata. 
Okazuje się, że większość badanych dzieci nie wie, ile potraw, zgodnie z tradycją, powinno się znaleźć na stole wigilijnym. Część osób nie zdaje sobie sprawy, że taka tradycja istnieje. Może to świadczyć o stopniowym zanikaniu utrwalonych zwyczajów w celebrowaniu świąt Bożego Narodzenia.

Podkategoria dotycząca nazw potraw, które powinny znaleźć się na wigilijnym stole, uruchomiła kolejną ścieżkę kognitywną. Najwięcej dzieci wskazało na: barszcz z uszkami (11) oraz rybę (11), w tym pangę (3) i karpia (2). Ośmioro badanych wymieniło ciasta, dodając, że mają na myśli sernik (3), sękacza (1) i piernik (1). W innych wypowiedziach wskazano: sałatki (6), pierogi z kapusta i grzybami (4), kutię (2), krokiety (1) oraz grzybki (1). Jeden z chłopców dodał, że nie powinno to być nic z pokarmów mięsnych. Pięć osób, po wyszczególnieniu różnych potraw, dodało: jeszcze dużo innych potraw powinno się znaleźć na stole wigilijnym, ale już zapomniałem/zapomniałam jakie.

Uczestniczące w badaniach dzieci potrafią wymienić podstawowe potrawy (dwie, trzy), jakie powinny znaleźć się na stole wigilijnym. Może to wynikać stąd, że w ich umysłach wiedza odnosząca się do tego fragmentu rzeczywistości nie jest jeszcze utrwalona, a jedynie „odświeżana” podczas kolejnych świąt Bożego Narodzenia.

\section{Wnioski}

Przedstawione wypowiedzi są próbą ukazania dziecięcych wyobrażeń na temat dwu wybranych świąt katolickich obchodzonych w naszym kraju. Odtworzenie definicji kognitywnych zostało oparte na wiedzy i doświadczeniu uczniów czwartej klasy szkoły podstawowej. Wydaje się, że była to próba udana, choć grupa badawcza nie jest w żadnej mierze reprezentatywna. Materiał leksykalny pozyskany od piętnaściorga dzieci jest zbyt skromny, aby na jego podstawie wyciągać pełne wnioski i formułować uogólnienia. Niemniej jednak przedstawiona analiza pokazała całościowy obraz świąt utrwalony w umysłach dziesięcioletnich dzieci, zgodny z informacjami, które możemy odnaleźć chociażby w źródłach internetowych ${ }^{49}$. Niekiedy dziecięce konkretyzacje były nawet bogatsze.

${ }^{49}$ Chociaż tradycja związana z obchodzeniem świąt Bożego Narodzenia oraz Wielkanocy jest powszechnie znana, poniżej przywołujemy krótki opis zwyczajów im towarzyszących, w celu zobrazowania, że wiedza, jaką posiadają w swoich umysłach dziesięcioletnie dzieci, zasadniczo nie różni się od informacji, które możemy znaleźć chociażby w dostępnych źródłach internetowych. 
Zgodnie z założeniem kognitywizmu język stanowi integralną część ludzkiego poznania, wnikliwa analiza zjawisk językowych winna zaś być osadzona w kontekście zdolności poznawczych człowieka (tu: dziesięcioletnich dzieci). Wydaje się, że uczniowie czwartej klasy dysponują odpowiednim zasobem wiedzy na temat zjawisk otaczającej rzeczywistości. Posiadają tym samym kompetencję kulturową, która budowana jest przy udziale języka. „To w języku zawarte są narosłe przez wieki interpretacje zjawisk rzeczywistości”"50 — pisze Stanisław Grabias. Choć zdaniem wielu badaczy dzieci nie myślą dokładnie tego, co dorośli użytkownicy języka im przekazują, to badania dowiodły, że mają one niezwykle bogatą wiedzę na temat tradycji związanej z obchodami

„W Polsce święta Bożego Narodzenia poprzedzone są, zwaną regionalnie Gwiazdką, czyli Wigilią, która przypada 24 grudnia. Wskazana jest wtedy wstrzemięźliwość od pokarmów mięsnych. Zwieńczeniem tego dnia jest uroczysta kolacja wigilijna, do której zasiada się wraz z całą rodziną, a rozpoczyna się ją po ujrzeniu na niebie pierwszej gwiazdy (na cześć gwiazdy, która prowadziła Trzech Króli do Dzieciątka). Według tradycji stół wigilijny powinien być przykryty białym obrusem, pod którym znajduje się wiązka sianka. Ponadto umieszcza się na nim jedno dodatkowe nakrycie przeznaczone dla niespodziewanego gościa. Zgodnie z obyczajem winno się przygotować 12 tradycyjnych potraw, między innymi: barszcz z uszkami, kapusta z grochem, kompot z suszu, ryby, śledzie, kluski z makiem, kutia. Wieczerzę należy rozpocząc modlitwą i czytaniem Ewangelii św. Mateusza lub św. Łukasza o narodzinach Jezusa. Następnie wieczerzający dzielą się opłatkiem i składają sobie świąteczne życzenia na przyszły rok. Istotnym zwyczajem obecnym podczas wigilii Bożego Narodzenia jest wspólne śpiewanie kolęd. Pod choinką natomiast umieszczane są prezenty. O północy w kościołach rzymskokatolickich odbywa się msza święta — pasterka". https://pl.wikipedia.org/wiki/Wigilia_Bo\%C5\%BCego_Narodzenia; https:// pl.wikipedia.org/wiki/Bo\%C5\%BCe_Narodzenie [data dostępu: 19.01.2018].

„Wielkanoc (inaczej Niedziela Wielkanocna, Wielka Niedziela, Zmartwychwstanie Pańskie) jest to najstarsze i najważniejsze święto obchodzone w Kościele chrześcijańskim wyznających Nicejskie Credo, ku czci zmartwychwstania Jezusa Chrystusa. W obrządku rzymskim zaczyna się ona już w sobotę po zapadnięciu zmroku. Wielkanoc jest poprzedzona czterdziestodniowym postem, rozpoczynającym się w Środę Popielcową". https://pl.wikipedia.org/wiki/Wielkanoc [data dostępu: 19.01.2018].

„W Kościele rzymskokatolickim ostatni tydzień przed Wielkanocą, zwany Wielkim Tygodniem, jest czasem rozpamiętywania i rozmyślań nad najważniejszymi dla chrześcijan wydarzeniami. Trzy ostatnie doby tego okresu: Wielki Czwartek (wieczór), Wielki Piątek, Wielka Sobota i Wielka Niedziela noszą nazwę Triduum Paschalne. Według tradycji, stół świąteczny powinien być przykryty białym obrusem i udekorowany liśćmi bukszpanu. Na środku stołu stawiamy baranka, np. na łączce z rzeżuchy. Rzeżucha to symbol sił witalnych i rodzącego się życia. W Niedzielę Wielkanocną świętujemy! Wstajemy bardzo wcześnie, by pójść na mszę zwaną rezurekcyjną. Niedziela to najważniejsze święto chrześcijańskie, nazywane dawniej Paschą. Następnie zasiadamy do świątecznego rodzinnego śniadania. Wielkanocna Niedziela to czas przeznaczony na rodzinne biesiadowanie. Dzieci bawią się w poszukiwanie prezentów podrzuconych przez zajączka". https://dziecisawazne.pl/tradycje-wielkanocne-jak-to-bylo-kiedys/; https://pl.wikipedia. org/wiki/\%C5\%9Awi\%C4\%99conka [data dostępu: 19.01.2018].

${ }^{50}$ S. Grabias: Teoria zaburzeń mowy. Perspektywy badań, typologie zaburzeń, procedury postepowania logopedycznego. W: Logopedia..., s. 52. 
Bożego Narodzenia i Wielkanocy. Często ich wypowiedzi są bardzo zindywidualizowane, lecz zawsze mieszczą się

w polu kulturowej wspólnoty znaczeń i adekwatności praktycznej; mogą też być po prostu błędne, np. wskutek nietrafnej eksploracji z jednych obszarów rzeczywistości na inne. Zawsze jednak są wynikiem mentalnej negocjacji znaczeń wynikających z doświadczania świata poprzez jego obserwację, działanie w nim i uczestniczenie w procesach komunikacjis1 .

\section{Bibliografia}

Bartmiński J.: Definicja kognitywna jako narzędzie opisu konotacji. W: O definicjach i definiowaniu. Red. J. Bartmiński, R. Tokarski. Lublin 1993.

Bartmiński J., Tokarski R.: Definicja semantyczna: czego i dla kogo?. W: O definicjach i definiowaniu. Red. R. Tokarski. Lublin 1993.

Bartmiński J.: O profilowaniu i profilach raz jeszcze. W: O definicjach $i$ definiowaniu. Red. J. Bartmiński, R. Tokarski. Lublin 1993.

Bartmiński J., Niebrzegowska S.: Profile a podmiotowa interpretacja świata. W: Profilowanie w języku i w tekście. Red. J. Bartmiński, R. Tokarski. Lublin 1998.

Bartmiński J.: Punkt widzenia, perspektywa, językowy obraz świata. W: Językowy obraz świata. Red. J. Bartmiński. Lublin 1999.

Bartmiński J., Panasiuk J.: Stereotypy językowe. W: Wspótczesny język polski. Red. J. Bartmiński. Lublin 2001.

Boniecka B.: Dziecięce wyobrażenie świata. Zbiór studiów. Lublin 2010.

Borowiec H.: Dziecięce rozumienie świata (studium lingwistyczne). Lublin 2014.

Buchowski M., Burszta W.J.: Antropologia kognitywna: charakterystyka orientacji. W: Amerykańska antropologia kognitywna. Poznanie, język, klasyfikacja, kultura. Wybór i red. M. Buchowski. Warszawa 1993.

Grabias S.: Teoria zaburzeń mowy. Perspektywy badań, typologie zaburzeń, procedury postepowania logopedycznego. W: Logopedia. Teoria zaburzeń mowy. Red. S. Grabias, M. Kurkowski. Lublin 2014.

Heinz A.: Język a inne dziedziny działalności człowieka. „Biuletyn Polskiego Towarzystwa Językoznawczego" 1981, z. 38.

Kardela H.: Ogdena i Richardsa trójkąt uzupetniony, czyli co bada gramatyka kognitywna. W: Językowy obraz świata. Red. J. Bartmiński. Lublin 1999.

Krakowiak K.: Wspólne doświadczanie języka. (Rozważania o wychowaniu językowym dzieci z uszkodzeniami stuchu). W: Język, człowiek, społeczeństwo. Księga jubileuszowa dedykowana Profesorowi Stanisławowi Grabiasowi. Red. J. Panasiuk, T. Woźniak. Lublin 2013.

Lakoff G., Jonhson M.: Metafory w naszym życiu. Tłum. T. Krzeszowski. Warszawa 1988.

Marody M.: Technologie intelektu. Językowe determinanty wiedzy potocznej i ludzkiego działania. Warszawa 1987.

${ }^{51}$ Światy dziecięcych znaczeń..., s. 18. 
Niesporek-Szamburska B.: Językowy obraz pór roku i tradycji kulturowych w twórczości dzieci. Katowice 2004.

Piaget J.: The Theory of Stages in Cognitive Development. W: Measurement and Piaget. Ed. D. Green, M. Ford, G. Flamer. New York 1971.

Piaget J.: The Affective Unconscious and the Cognitive Unconscious. W: Piaget and His School. Ed. B. Inhelder, M. Chapman. New York 1976.

Rosch E.: Principles of Categorization. W: Cognition and Categorization. Ed. E. Rosch, B. Lloyd. Hillsdale 1978.

Światy dziecięcych znaczeń. Red. D. Klus-Stańska. Warszawa 2004.

Tabakowska E.: Gramatyka i obrazowanie. Wprowadzenie do językoznawstwa kognitywnego. Kraków 1995.

Tschirch F.: Denkform und Sprachgestalt. Grundauffassungen und Fragestellungen in der heutigen Sprachwissenschaft. Berlin 1954.

Tokarski R.: Ramy interpretacyjne a problemy kategoryzacji (przyczynek do tak zwanej definicji kognitywnej). W: Językowa kategoryzacja świata. Red. R. Grzegorczykowa, A. Pajdzińska. Lublin 1996.

Wierzbicka A.: Lexicography and Conceptual Analysis. Ann Arbor 1985.

Wittgenstein L.: Dociekania filozoficzne. Thum. B. Wolniewicz. Warszawa 1972.

Wiśniewska-Kin M.: „Chcieć, pragnać, myśleć, wiedzieć” — rozumienie pojęć przez dzieci. Kraków 2007.

Wiśniewska-Kin M.: „Miłość jest jak wiatrak” - czyli o poznawczej naturze metafor dziecięcych. Łódź 2009.

Wiśniewska-Kin M.: Dziecięce rozumienie świata - w poszukiwaniu uzasadnień postępowania badawczego. „Problemy Współczesnej Edukacji” 2016, nr 1.

Vasta R., Haith M.M., Miller S.A.: Psychologia dziecka. Warszawa 1995.

Załazińska A.: Niewerbalna struktura dialogu. W poszukiwaniu polskich wzorców narracyjnych i interakcyjnych zachowań komunikacyjnych. Kraków 2006.

\section{Źródła internetowe}

https://dziecisawazne.pl/tradycje-wielkanocne-jak-to-bylo-kiedys/.

https://pl.wikipedia.org/wiki/\%C5\%9Awi\%C4\%99conka.

https://pl.wikipedia.org/wiki/Bo\%C5\%BCe_Narodzenie.

https://pl.wikipedia.org/wiki/Wielkanoc.

https://pl.wikipedia.org/wiki/Wigilia_Bo\%C5\%BCego_Narodzenia.

https://sjp.pwn.p1/. 